\title{
Pilot Peat-Bed Treatment System for NPDES Outfall H-12
}

\author{
Nancy V. Halverson \\ Ralph L. Nichols \\ Christopher J. Berry
}

October 22, 2007 


\section{DISCLAIMER}

This report was prepared for the United States Department of Energy under Contract No. DE-AC0996SR18500 and is an account of work performed under that contract. Neither the United States Department of Energy, nor WSRC, nor any of their employees makes any warranty, expressed or implied, or assumes any legal liability or responsibility for accuracy, completeness, or usefulness, of any information, apparatus, or product or process disclosed herein or represents that its use will not infringe privately owned rights. Reference herein to any specific commercial product, process, or service by trade name, trademark, name, manufacturer or otherwise does not necessarily constitute or imply endorsement, recommendation, or favoring of same by Washington Savannah River Company or by the United States Government or any agency thereof. The views and opinions of the authors expressed herein do not necessarily state or reflect those of the United States Government or any agency thereof.

Printed in the United States of America

Prepared For

U.S. Department of Energy 


\section{TABLE OF CONTENTS}

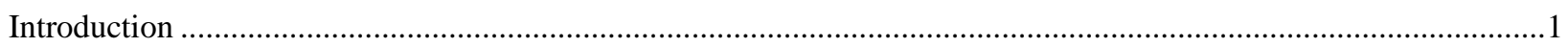

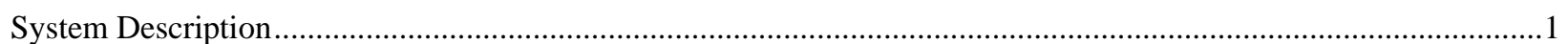

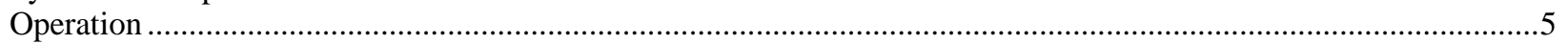

Observation, Sampling and Analysis Plan.................................................................................................

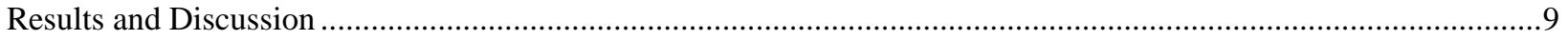

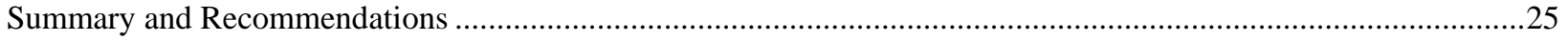

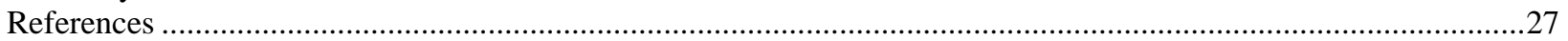

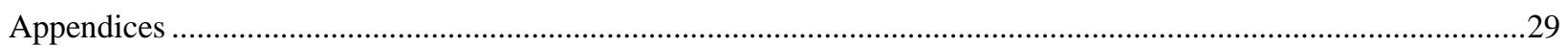

\section{FIGURES}

Figure 1. Location of the Pilot Peat-Bed Treatment Systems ................................................................................2

Figure 2. Tank \#1 - Premier Pro-Moss TBK Peat Treatment Tank ................................................................................

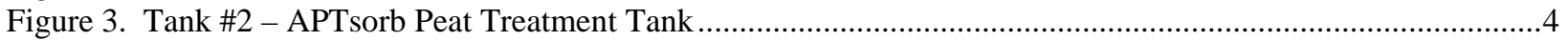

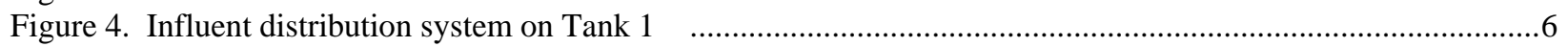

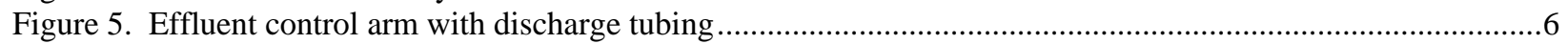

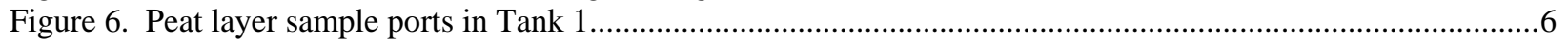

Figure 7. Access deck - Tank 1 on the right and Tank 2 on the left..........................................................................6

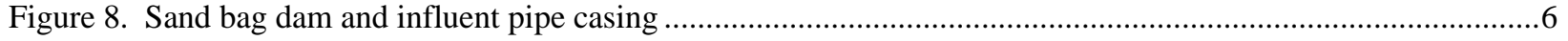

Figure 9. New water supply pump with overflow back to Outfall H-12 .............................................................6

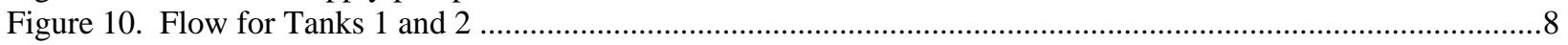

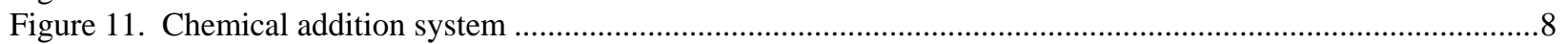

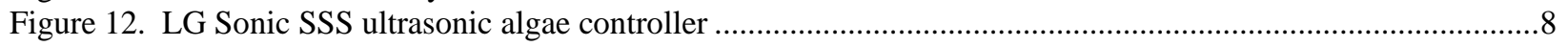

Figure 13. Peat adsorption isotherms of copper.....................................................................................................11

Figure 14. Peat adsorption isotherms of copper, low level $(<1 \mathrm{mg} / \mathrm{L})$..................................................................11

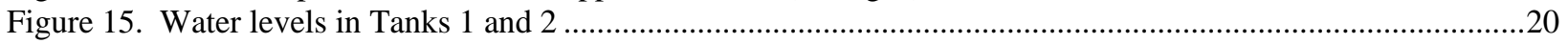

Figure 16. Monitoring points and material layers in Tank1 ..................................................................................

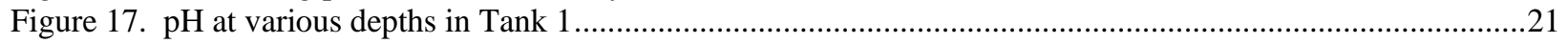

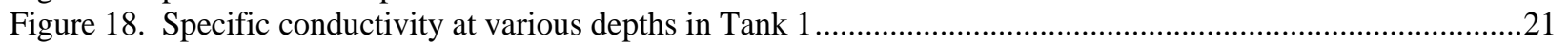

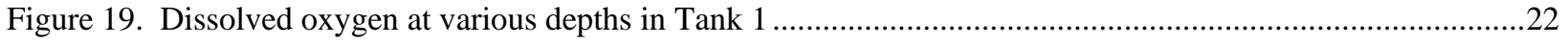

Figure 21. Water level and flow rate trends for Tank 1...................................................................................24

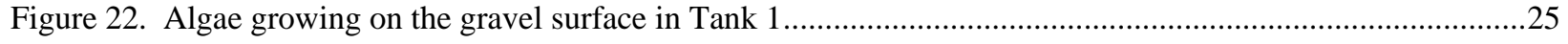

Figure 23. Algae growing on the peat in Tank 2 where the surface was disturbed ..................................................25

\section{TABLES}

Table 1. Results from analysis of materials and leach water ...........................................................................10

Table 2. TSS and Metals Results for Peat-Bed Pilot Study Tank 1 ….....................................................................12

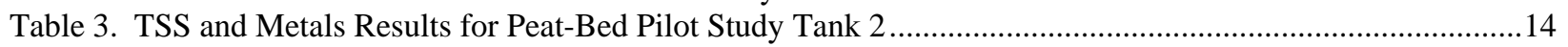

Table 4. pH Measurements for Peat-Bed Pilot Study Tank 1 .................................................................................17

Table 5. pH Measurements for Peat-Bed Pilot Study Tank 2 ...................................................................................18

Table 6. Radiological Screening Results for Tank 1 Water Samples .........................................................................18

Table 7. Radiological Screening Results for Tank 2 Water Samples .....................................................................19

Table 8. Results from hydraulic conductivity measurements at Tank 1 ..................................................................23

Table 9. Comparison with hydraulic conductivity values in other studies ...............................................................23 


\section{Pilot-Scale Peat-Bed Treatment System for NPDES Outfall H-12}

\section{Introduction}

A National Pollutant Discharge Elimination System (NPDES) Permit was issued to the Savannah River Site (SRS) by the South Carolina Department of Health and Environmental Control (SCDHEC) and became effective on December 1, 2003. The new permit contained revised limits for copper and zinc derived by adjusting the South Carolina aquatic life water quality standards in accordance with dissolved metals criteria. The new copper and zinc limits are very low and may not be met consistently at Outfall H-12. The outfall has periodically exceeded the new 6 $\mu \mathrm{g} / \mathrm{l}(0.006 \mathrm{mg} / \mathrm{L})$ monthly average limit and the $8 \mu \mathrm{g} / \mathrm{l}(0.008 \mathrm{mg} / \mathrm{L})$ maximum limit for copper and recently has begun exceeding the $100 \mu \mathrm{g} / \mathrm{l}(0.100 \mathrm{mg} / \mathrm{L})$ limit for zinc. The compliance date for Outfall H-12 is November 1 , 2008. A study was conducted on this outfall and other outfalls to evaluate possible alternatives for meeting the new permit limits (Shipman and Bugher 2004). The study team recommended construction of a peat bed for treatment of the Outfall H-12 effluent. This recommendation was repeated by a second alternatives study team in 2007 (WSRC 2007).

A bench-scale laboratory study demonstrated the feasibility of peat-bed treatment for Outfall H-12 effluent, with the peat demonstrating excellent removal of copper (Nelson and Specht 2005). An additional study was performed in 2006 and early 2007 using vertical-flow peat columns to investigate the influence of water retention time (contact time) on the removal of copper and zinc from the water (Nelson 2007c). Analytical results indicated that copper removal was very high at each of the three retention times tested, ranging from $99.6 \%$ removal at five and three hours to $98.8 \%$ removal at one hour. Effluent copper levels from these studies were much lower than the new compliance limit for the outfall. Most divalent metals, including zinc, were removed to below their normal reporting detection limit.

The H-Area Material Disposition organization requested a larger-scale study to investigate key design and operation parameters/issues, such as the possibility of rapid plugging of the piping or clogging of the peat bed, the effectiveness of the treatment, hydraulic conductivity, etc. The resulting pilot-scale facility was constructed adjacent to Outfall H-12 with SCDHEC approval (Mullinax 2007). The pilot-scale study was performed by the Savannah River National Laboratory’s (SRNL) Environmental Science and Biotechnology Directorate personnel.

Since the construction and operation of the pilot-scale peat bed facility, however, a new strategy for achieving compliance of Outfall H-12 effluent with the new permit limits has been selected. This new strategy incorporates a variety of efforts including source reduction, recalculation of limits using an aquatic species that is indigenous to the area instead of a standard species, and dissolved organic carbon addition to reduce copper toxicity.

This report documents the construction and operation of the pilot-scale treatment system, the results obtained, and recommendations on the usefulness of this technology for Outfall H-12 or other outfalls at SRS.

\section{System Description}

Two pilot-scale peat-bed systems were temporarily installed between NPDES Outfall $\mathrm{H}-12$ and the 281-8H basin (Figure 1). The systems were fabricated using cross-linked polyethylene tanks (Figure 2 and Figure 3). The primary difference between the two peat-bed systems was the type of peat used. Tank 1 was constructed with Pro-Moss TBK, a long-fibered blond sphagnum peat moss from Premier Horticulture in Canada. The Pro-Moss TBK was chosen for its high fibrosity, water retention and air porosity. Twenty-two of the 3.8 cubic foot bales were used in the tank. Each bale of peat was placed in the tank and broken up to eliminate large clumps. Tank 2 was constructed with APTsorb, a granular peat product produced by American Peat Technology, LLC. APTsorb was developed for the removal of heavy metals and organics from wastewater flows. It uses a reed-sedge peat to which about $5 \%$ calcium carbonate powder has been added (Paulson 2007). The mixture is formed into pellets and then ground to a coarse coffee ground texture. 


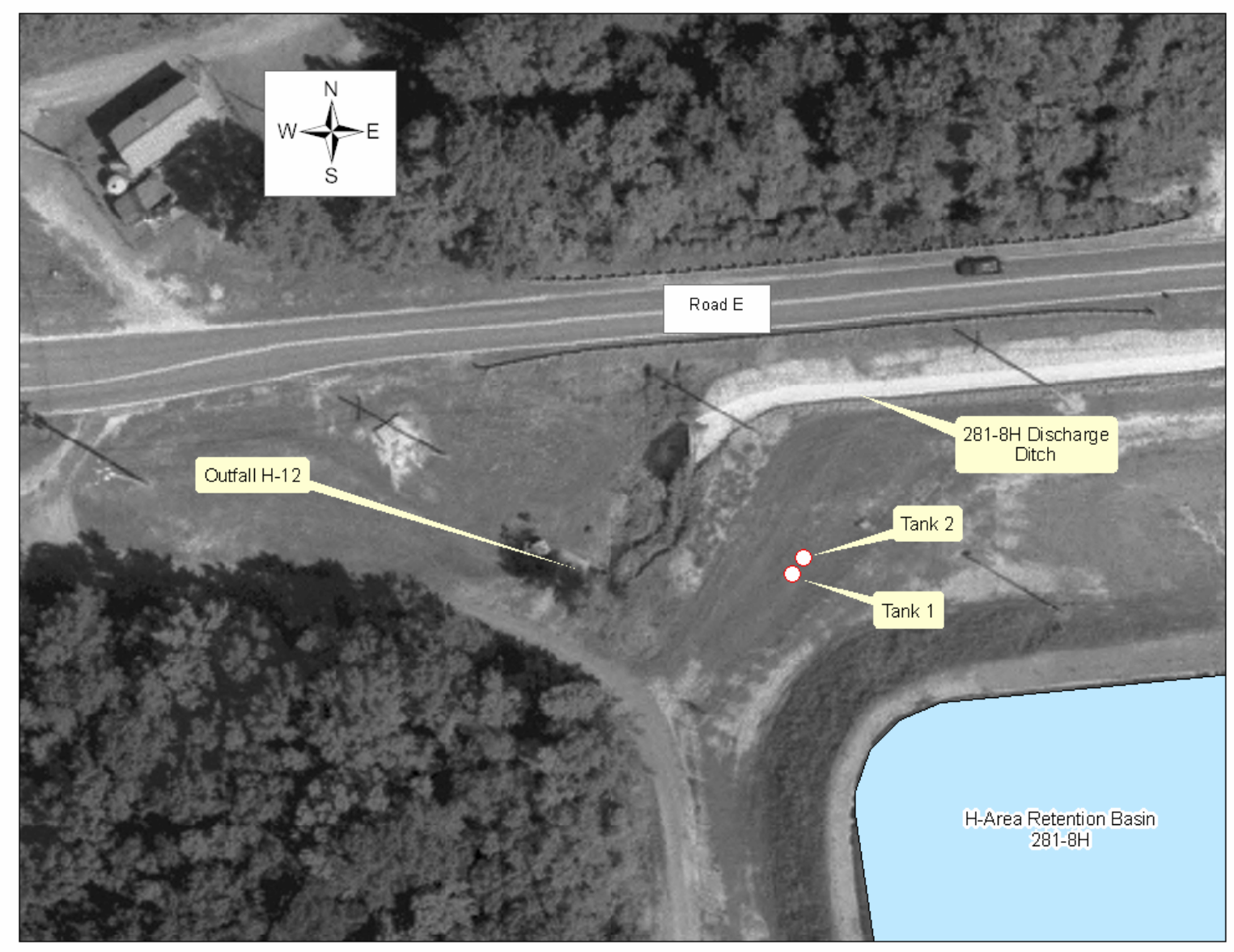

Figure 1. Location of the Pilot Peat-Bed Treatment Systems 


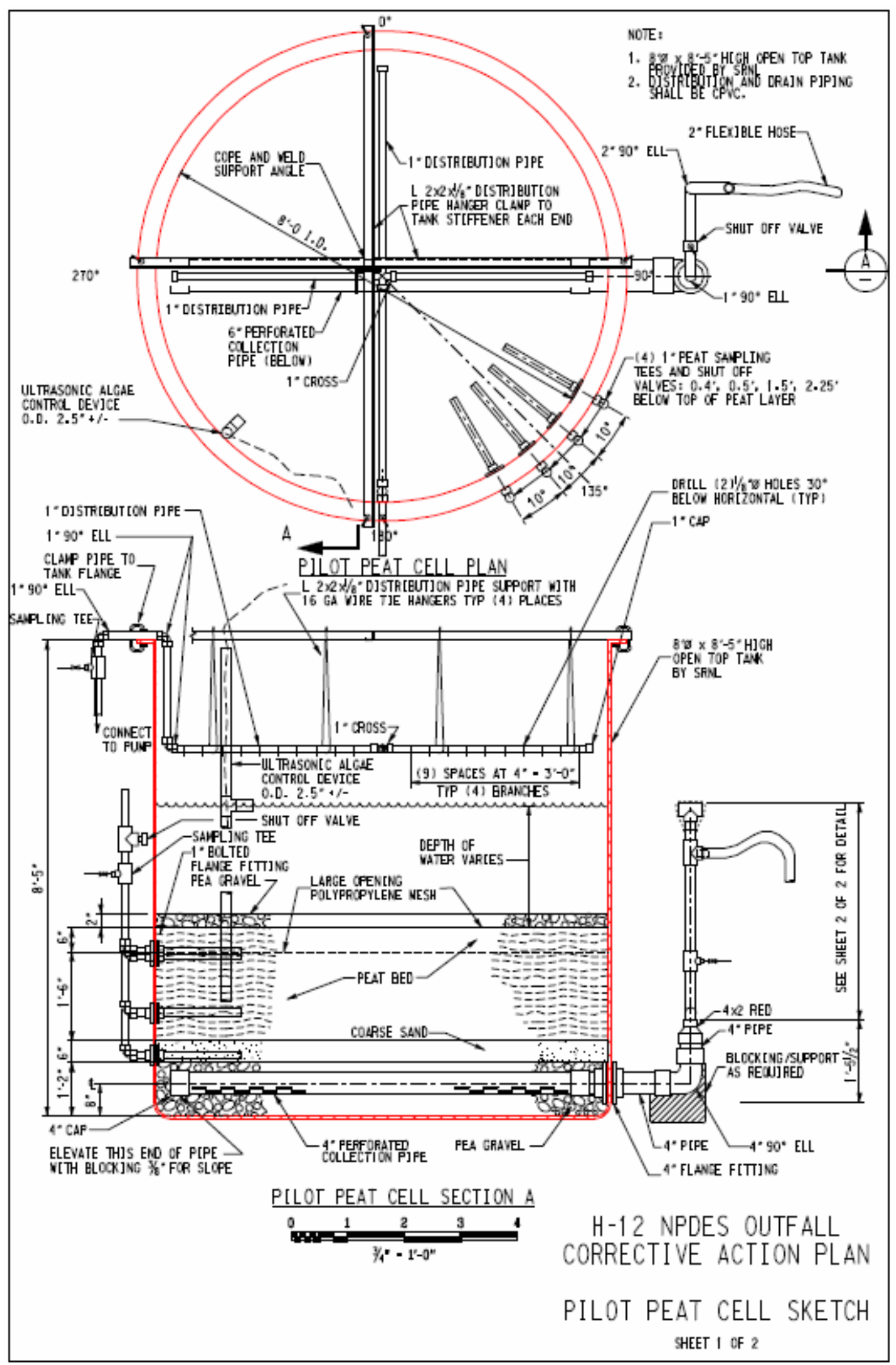

Figure 2. Tank \#1 - Premier Pro-Moss TBK Peat Treatment Tank 


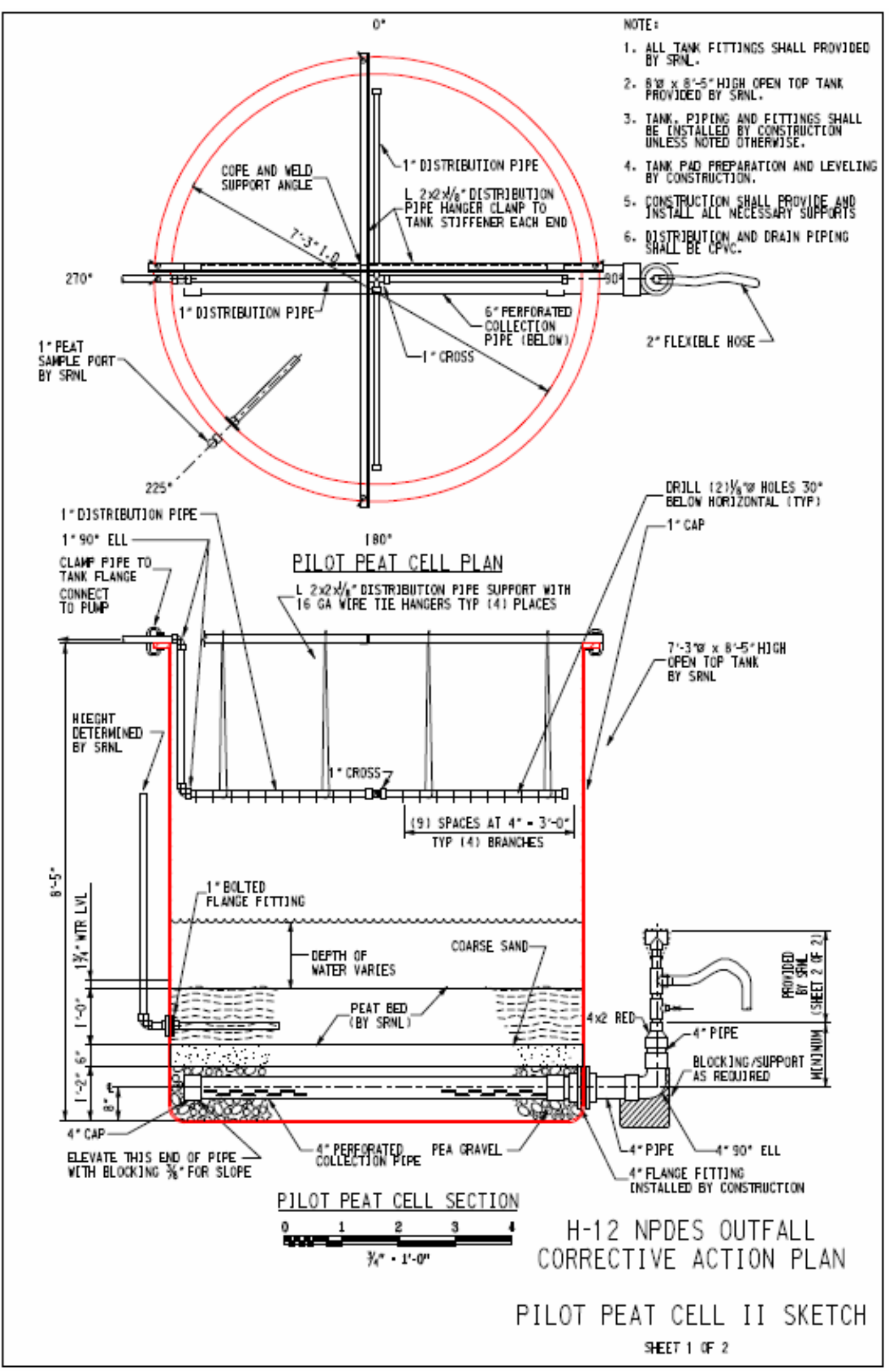

Figure 3. Tank \#2 - APTsorb Peat Treatment Tank 
Tank 1 consisted of the following layers, listed from bottom to top (Figure 2):

- 14" sub-drain layer of washed pea gravel with 4" diameter perforated PVC effluent piping at $0.5 \%$ slope

- 6" thick filter layer of coarse washed sand with hydraulic permeability of greater than $1 \times 10^{-2} \mathrm{~cm} / \mathrm{s}(0 \%$ passing Number 100 sieve)

- 18” thick layer of Pro-Moss TBK peat (see Appendix 1 for the technical data sheet)

- Separation layer of polypropylene mesh with openings 10.2 x 10.2 per square inch

- 6" thick layer of Pro-Moss TBK peat

- Layer of polypropylene mesh with openings 10.2 x 10.2 per square inch on the top of the peat

- 2" cover layer of washed pea gravel

Tank 2 was constructed in a similar manner to Tank 1, with the major difference being the layers inside the tank. Tank 2 consisted of the following layers, listed from bottom to top (Figure 3):

- 14" sub-drain layer of washed pea gravel with 4" diameter perforated PVC effluent piping at $0.5 \%$ slope

- 6" thick filter layer of coarse washed sand with hydraulic permeability of greater than $1 \times 10^{-2} \mathrm{~cm} / \mathrm{s}(0 \%$ passing Number 100 sieve)

- 1' thick layer of APTsorb peat (see Appendix 2 for the specifications).

The influent distribution system suspended across the top of each tank consisted of 1 " PVC piping with $1 / 8$ " perforations drilled into the lower sides (Figure 4). The effluent structure for each tank had an adjustable arm to control water level, flow out of the system, and residence time in the system (Figure 5). The effluent control arm was adjusted to maintain a head of a foot or more of water over the peat to prevent the peat from drying. Sample ports through the side of the tank connected to perforated piping installed at various depths in the peat layer and extending 18” into the tank (Figure 6). The sample ports allowed measurement of various parameters and hydraulic head at different depths in the peat and calculation of hydraulic conductivity. An access deck was built around the tanks (Figure 7).

A low sand-bag dam was placed in the Outfall H-12 stream, upstream of the NPDES sample station, to provide a pool of water during low flow periods (Figure 8). Two-inch stainless steel wire-wrapped 0.010 inch slot well screen and casing were used to construct an intake structure to house a submersible pump used to deliver water to the pilot scale treatment system. The screen and casing armored the pump and prevented particulates down to fine sand in size from entering the pump. Initially, a $1 / 2 \mathrm{hp}$ variable speed Grundfos RediFlo2 pump was used to deliver water to the pilot scale treatment system. The variable speed pump was operated by a variable frequency drive which enabled good flow control. A $1 / 2$ ” hose connected the pump to the influent distribution piping.

After two such pumps failed, a different pump was installed on July 13 . The new pump was a $3 / 4$ hp Dayton nonsubmersible centrifugal pump model 2P004. The suction tubing to the pump was inserted into the same stainless steel casing with well screen that was used with the other pumps. Because this was not a variable speed pump, flow to the tanks was controlled by valves installed along the intake piping, and excess water pumped from the Outfall $\mathrm{H}$ 12 stream was returned to the stream, bypassing the peat tanks (Figure 9).

A 2" transparent tube (to allow a visual indicator of flow) collected the peat-bed effluent at the end of each of the adjustable arms (Figure 5) and routed it to a 2" PVC pipe leading back to the wastewater stream, downstream of the sand-bag dam but upstream of the NPDES outfall.

\section{Operation}

Construction of Tank 1 was completed on the morning of Thursday, May 31, 2007. The influent hose was connected to the effluent control piping to allow the tank to be filled from the bottom to ensure complete hydration of the peat. Filling began at 11:45 AM on May 31. Pumping was halted in the late afternoon and restarted the following morning to finish filling the tank. The pump was stopped again that afternoon, and the peat was allowed to hydrate over the weekend. On Monday, June 4, 2007, the influent and effluent tubing were adjusted to their operating positions and the pilot-scale treatment facility began operating. 


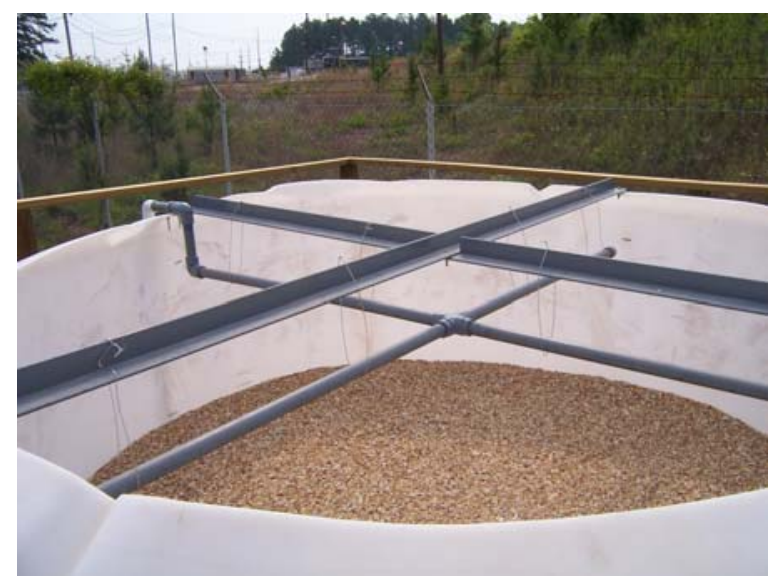

Figure 4. Influent distribution system on Tank 1

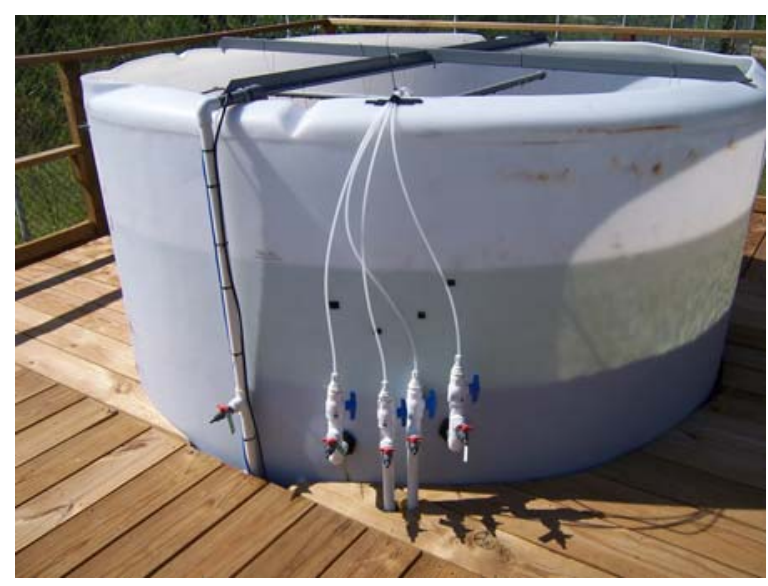

Figure 6. Peat layer sample ports in Tank 1

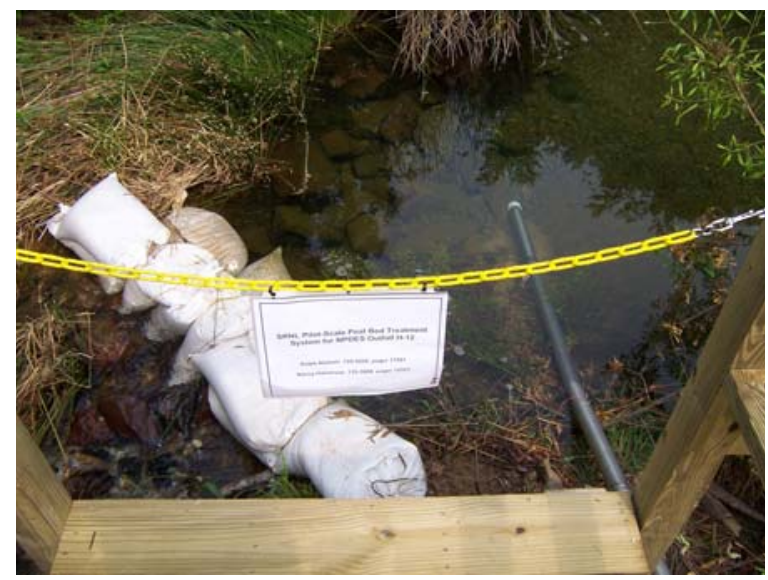

Figure 8. Sand bag dam and influent pipe casing

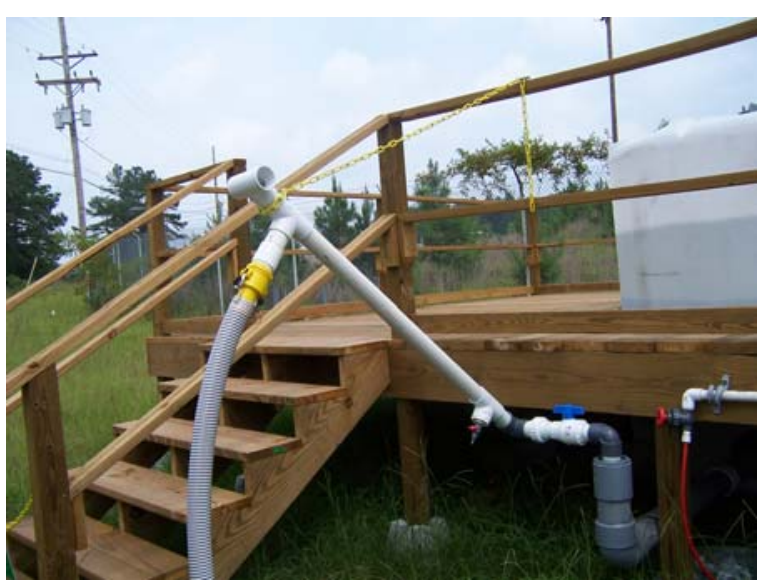

Figure 5. Effluent control arm with discharge tubing

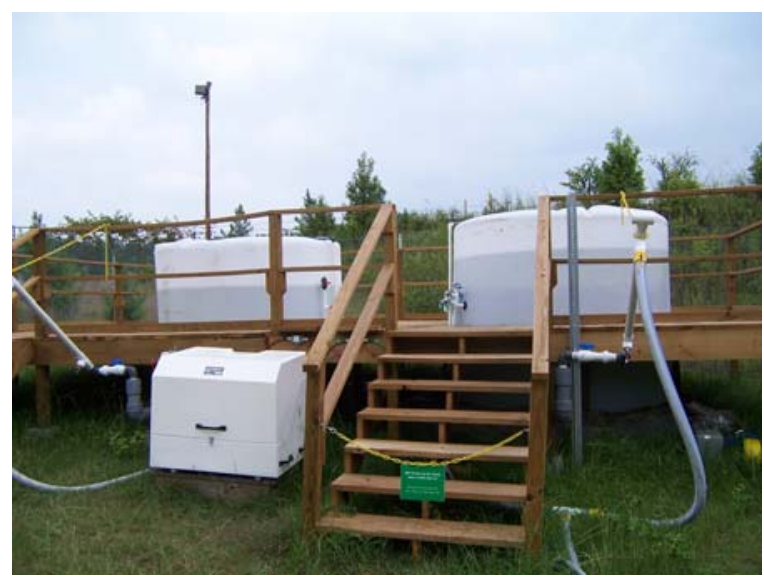

Figure 7. Access deck - Tank 1 on the right and Tank 2 on the left

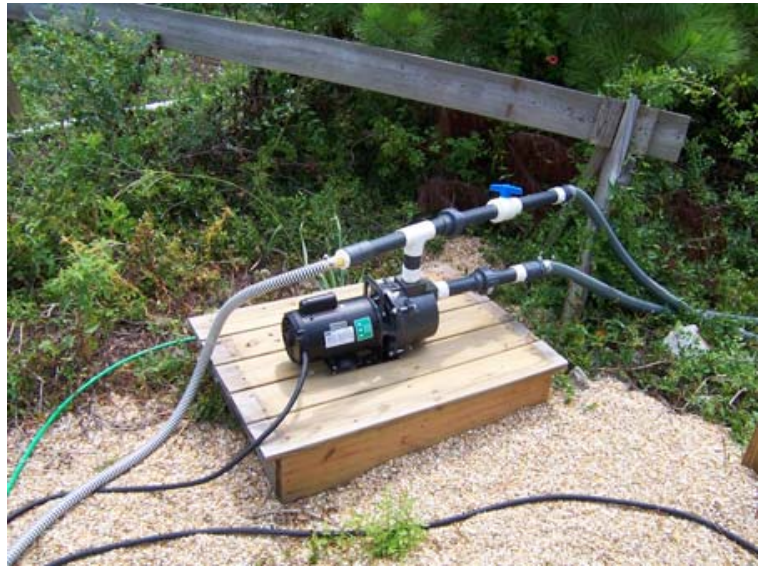

Figure 9. New water supply pump with overflow back to Outfall H-12 
For the first month, the Tank 1 peat-bed operated alone and functioned well, with the exception of a temporary problem with the power supply during the second week of operation. Nearly daily rainfall caused the ground-fault circuit interrupter (GFCI) to trip the breaker over the weekend of June 8-9 and the evenings of June 10, 11 and 12. On June 10, the breaker was reset in the morning and the tank was sampled several hours later, allowing the stagnant water to pass through the system before sampling. On June 11, the GFCI tripped repeatedly. The extension cords were replaced in an effort to solve the problem. However, by the time the pump was restarted, there was not sufficient time to flush the system and sample the tank. On June 12, a different enclosure was installed at the receptacle to try to keep out rainwater. Once again, the tank could not be sampled. On June 13, the 15-amp breaker was replaced with a 20 -amp breaker, which ended the power supply problems. Pumping resumed, and the tank was sampled several hours later.

An additional problem was noted in the third week of Tank 1 operation. On the afternoon of Monday, June 18, no flow was coming to Outfall $\mathrm{H}-12$. The pool of water upstream of the sand-bag dam was rapidly dwindling. Discussions with the Design Authority and Environmental Compliance Authority indicated this low flow condition could persist for several days. To avoid damage to the pump, the pump was turned off that afternoon around 2:30 PM. After confirming adequate flow at the outfall the following morning (6/19/07), the pump was restarted at about 10:00 AM. Arrangements were made with H-Area personnel to increase the rate of pumping make-up water from the process water wells to cooling tower basin $285-\mathrm{H}$. This increased the basin overflow, which ensured adequate flow would be maintained at the outfall for the duration of the study.

Tank 2 construction was completed on June 27. The influent hose was connected to the effluent control piping to allow the tank to be filled from the bottom to ensure complete hydration of the peat. Filling began at 10:42 AM on June 27. Pumping was halted on June 28, and the peat was allowed to hydrate over the weekend and the July $4^{\text {th }}$ holiday. Filling began again at 10:35 AM on July 5 and was completed at 11:30 July 6 . The peat was allowed to hydrate again over the weekend. On Monday, July 9, 2007, the influent and effluent tubing were adjusted to their operating positions and Tank 2 began operating.

In contrast to the power and water supply concerns, flow through the peat was trouble-free for most of the study period in spite of the algae growth that became apparent in early July. After the first few days of operation, a flow recorder was added to the system to allow continuous monitoring of the peat-bed influent. At the beginning of the study, the pumping rate to each tank was approximately $1 \mathrm{gpm}$, a rate chosen to mimic the cross-sectional flow rate for the full-sized system and to provide an approximately four hour retention time in the peat. In July, the project team decided to cut the full-size peat beds in half, requiring the design flow per unit area to be doubled. Consequently, the flow to the pilot study tanks was doubled to approximately 2 gpm on July 13. A graph of the flow to the tanks is shown in Figure 10.

The effluent arms were initially set to retain at least one foot of water over the top of the peat or gravel. On July 31, the level of water in Tank 1 was observed to be higher than the perceived normal level. The water level was marked and then checked the following day and found to be a few inches higher. The effluent arm for Tank 1 was dropped a few inches to ensure the tank would not overflow. Transducers were installed in each tank to monitor water depth.

During the operation of the pilot study, there were various non-standard flow conditions in H-Area facilities feeding Outfall H-12. These included an extended outage in $\mathrm{H}$ Canyon to repair a diversion valve, repairs being made to the Acid Recovery Unit, effluent normally destined for the smaller 241-103H basin being rerouted to the much larger 281-8H basin, and a site-wide power shortage which influenced some pumping operations. The first two of these conditions persisted throughout the entire study period to date and the latter condition for a week or so during midsummer. The impacts these non-standard flow conditions may have had on the "normal" flow and water chemistry at Outfall H-12 is not fully known. Similarly, the long-term effects of flow-path modifications that would be made as part of the full-sized peat bed construction and operation could result in undetermined changes in water chemistry compared to current water chemistry.

Possibly as a result of these non-standard flow conditions, the copper levels seen in the influent during the study were usually below the detection limit of $0.005 \mathrm{mg} / \mathrm{L}$. To ensure that the peat-bed performance could be measured, a copper addition system was installed on August 20 to raise the copper in the influent to above $0.010 \mathrm{mg} / \mathrm{L}$. Copper was added using a $50 \mathrm{mg} / \mathrm{L}$ copper (II) chloride $\left(\mathrm{CuCl}_{2}\right)$ solution. The system consisted of a $50 \mathrm{~L}$ carboy for the $\mathrm{CuCl}_{2}$ solution inside a plastic 55 gallon drum. A diaphragm metering pump mounted on a platform on top of the 


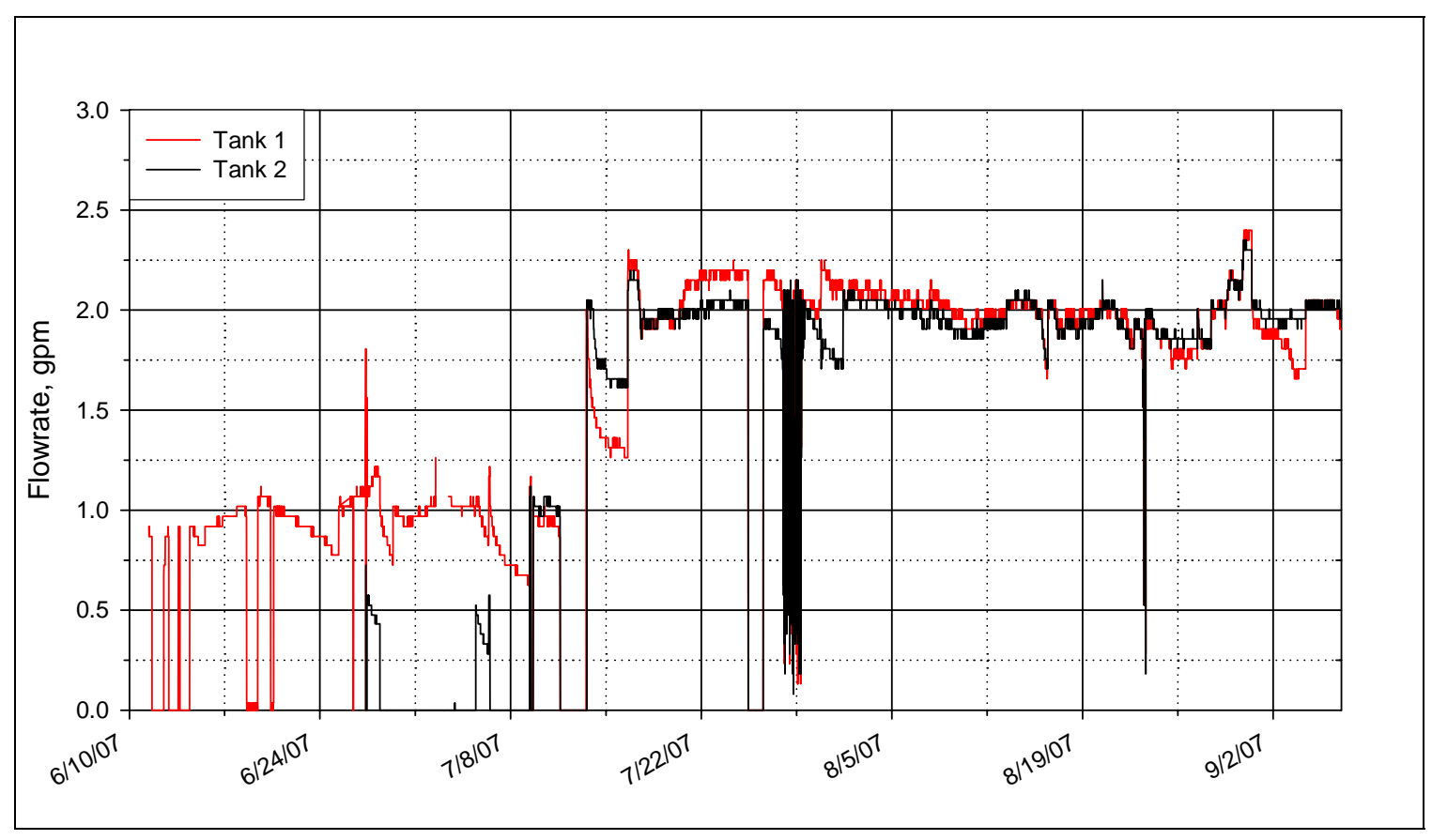

Figure 10. Flow for Tanks 1 and 2

carboy (Figure 11) was used to inject the stock solution into the influent line upstream of the manifold that controlled flow to the individual tanks. The injection tubing was made of $1 / 4$ " high density polyethylene and was equipped with a check valve to prevent source water from flowing into the stock tank in the event of a pump failure. The copper addition system operated continuously at a nominal flow rate of $6.5 \mathrm{~mL} /$ minute except for a few days beginning around September 9 or 10 when the system ran out of $\mathrm{CuCl}_{2}$ over a weekend.

Due to concerns over the possibility of the algae eventually causing clogging of the peat bed, a LG Sonic SSS ultrasonic algae control device was installed in Tank 1 on August 20 (Figure 12). A mounting device was constructed for the instrument using PVC pipe. To allow comparison of a treated tank vs. a non-treated tank, no algae control device was put into Tank 2.

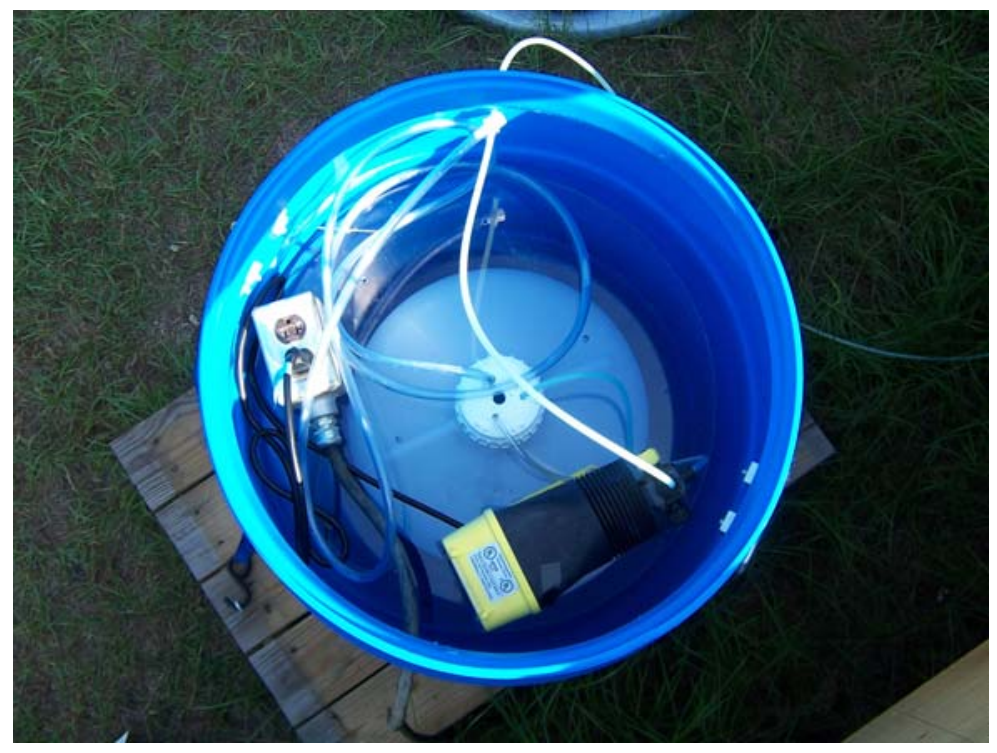

Figure 11. Chemical addition system

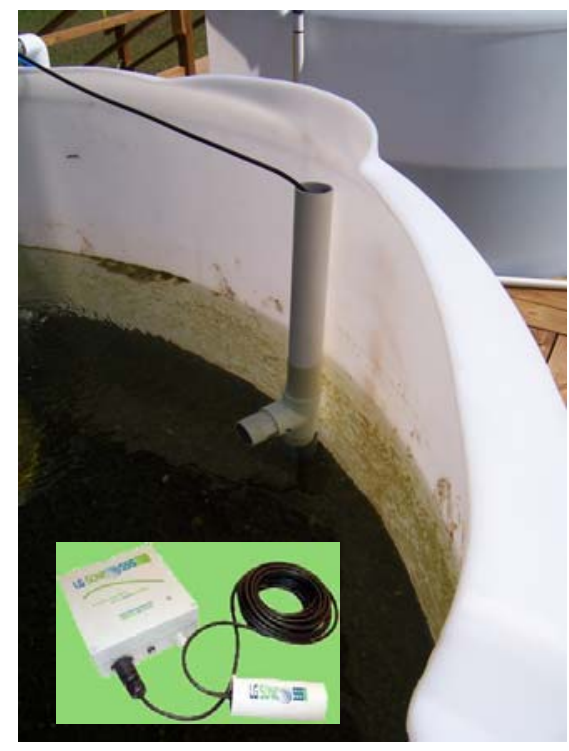

Figure 12. LG Sonic SSS ultrasonic algae controller 


\section{Observation, Sampling and Analysis Plan}

Samples of the sand and gravel used in constructing the peat beds were mixed with de-ionized water and placed on a shaker for four days. The water was then sent for copper and zinc analysis to ensure the construction materials themselves were not contaminated with the metals.

Batch scale testing was performed on the two types of peat to determine sorption isotherms using Outfall H-12 water spiked with copper. One method for assessing the biosorbent capacity of a material is the derivation of a sorption isotherm, which is the equilibrium between the concentration in the fluid phase and the concentration in the adsorbent particles at a given temperature. Equilibrium isotherms were determined by shaking a fixed mass of peat ( $0.5 \mathrm{~g}$ ) with $200 \mathrm{~mL}$ of Outfall H-12 effluent water and varying amounts of copper (II). Copper (II) concentrations ranged from 10 to $7.0 \mathrm{E}+04 \mu \mathrm{g} / \mathrm{L}$. Samples were shaken at room temperature until equilibrium had been achieved, usually 24 hours. Then samples were withdrawn, filtered through a $0.45 \mu \mathrm{m}$ membrane filter, and analyzed with inductively coupled plasma emission spectroscopy (ICPES).

The pilot study sampling plan (Halverson and Nichols 2007) called for daily (5 day weeks) sampling of the influent and effluent of each pilot study tank for one month, followed by weekly sampling through September. Influent and effluent samples were to be taken within a few minutes of each other as opposed to delaying the sampling of the effluent to catch the same slug of water that was sampled at the influent. These samples were to be analyzed for copper, zinc, lead and total suspended solids (TSS). The sampling plan also included field measurements of influent and effluent $\mathrm{pH}$ and biweekly sampling for radiological analysis. The plan was modified somewhat as the project progressed. The daily sampling of Tank 2 was dropped back to weekly sampling after only three weeks due to the low levels of influent copper. After the start-up of the copper addition system, sampling of both tanks was increased to three times weekly for several weeks to establish sufficient data to demonstrate the effectiveness of the peat-bed treatment. Samples for metals analysis were preserved with nitric acid. Samples were delivered directly to Environmental Monitoring Section laboratories for analysis or were refrigerated for a few days until delivery. Chains of custody were maintained. Duplicate samples were collected daily for the first week. Results for the duplicate samples showed good agreement (Appendix 4); therefore, duplicate sampling was reduced to once a week, or roughly $20 \%$, for the duration of the daily sampling period.

Influent flows and tank water levels were recorded by data logger. Flows to the tanks were recorded every 15 minutes. Water level measurements were recorded every 10 minutes. To maintain relatively steady flow into the tanks, influent valves had to be adjusted occasionally and the intake tubing well-screen had to be cleaned with a brush periodically to remove algae, sediments or other occlusive material.

Polyethylene (PE) tubing was attached to each of the sampling ports on the side of the Tank 1 to measure hydraulic head at several depths in the peat bed treatment system. The height of water in each $1 / 4$ " PE tube relative to the reference datum (top of deck floor) was measured using a standard steel measuring tape. Additionally, the water level in the tank and the height of the overflow in the effluent control arm were also measured using the same reference datum. The synchronous water level measurements were used to calculate the hydraulic conductivity of the different materials in the tank.

A YSI ${ }^{\circledR}$ multiparameter water quality meter was used to measure the water quality indicators, $\mathrm{pH}$, specific conductance, and dissolved oxygen, at different depths in the tank using the sampling ports and the influent and effluent to the tanks. Monitoring was performed using a flow-through cell on the probe connected to the sampling ports using tygon tubing. Water was allowed to flow through the cell until the readings from the probe had stabilized.

\section{Results and Discussion}

Leachate results for the sand and gravel used in constructing the peat beds are shown in Table 1. Results for copper and zinc, the two metals of primary concern, were undetectable. These results indicated that any copper or zinc 
Table 1. Results from analysis of materials and leach water

\begin{tabular}{ccc}
\hline Material & $\begin{array}{c}\text { Leachate Copper Concentration } \\
(\mathbf{m g} / \mathbf{L})^{*}\end{array}$ & $\begin{array}{c}\text { Leachate Zinc Concentration } \\
(\mathbf{m g} / \mathbf{L})\end{array}$ \\
\hline Sand & $<0.01(0.0012)$ & $<0.01$ \\
Gravel & $<0.01(0.0051)$ & $<0.01$ \\
\hline
\end{tabular}

* Results in parentheses are instrument readings below the practical quantitation limit (PQL)

found in the effluent during the operation of the peat beds would not have been introduced to the system by these construction materials.

The adsorption isotherms for the Premier Pro-Moss TBK peat and the APTsorb peat are shown in Figure 13. Figure 14 shows the two adsorption isotherms at liquid equilibrium concentrations less than $1 \mathrm{mg} / \mathrm{L}$. The adsorption isotherms plot the equilibrium relationship between the concentration of copper in the fluid phase and the concentration of copper in the peat particles, giving a measurement of the capability of the two types of peat to adsorb copper. The results indicated that the APTsorb peat adsorption capacity and holding capacity for copper were larger than for the Premier peat, but that adsorption by the Premier peat was strongly favorable at copper concentrations likely to be seen at Outfall H-12. The loading of copper on the Premier peat was higher at these lower concentrations compared with the APTsorb peat. The APTsorb peat was favorable only at higher concentrations, > $20 \mathrm{mg} / \mathrm{L}$. More details of this batch testing can be found in Berry (2007 DRAFT).

The metals results received to date for Tank 1 are shown in Table 2. The results showed that the peat bed operated effectively, reducing copper and zinc levels to below the detection limits (i.e. practical quantitation limits, or PQLs) of $0.005 \mathrm{mg} / \mathrm{L}$ and $0.01 \mathrm{mg} / \mathrm{L}$, respectively, which are also below the new permit limits. The increase in flow from 1 gpm to 2 gpm during the study did not have a negative impact on the treatment effectiveness. Because the copper levels were frequently below the detection limit even in the influent, the instrument readings are reported where available in Table 2 alongside the "less than" values to show the difference between the influent and effluent copper concentrations. These instrument readings are displayed for information only. Before the addition of copper chloride to the influent, copper in the influent ranged from less than detectable $(<0.005 \mathrm{mg} / \mathrm{L})$ to $0.0174 \mathrm{mg} / \mathrm{L}$ and exceeded the new permit limit on 7 days. The addition of copper chloride to the influent water, starting after the August 20 samples were collected, increased the incoming copper levels to as high as $0.049 \mathrm{mg} / \mathrm{L}$. However, copper in the effluent remained below detectable in all samples. Using instrument readings when results were less than the detection limit, removal rates for copper from mid-June (after power supply problems were resolved) through September were calculated. Results ranged from $89 \%$ to $100 \%$ removal, averaging $99 \%$. Zinc in the influent ranged from less than detectable ( $<0.01 \mathrm{mg} / \mathrm{L})$ to $0.176 \mathrm{mg} / \mathrm{L}$ and exceeded the new permit limit on 7 days. Effluent zinc levels were measurable in the early samples, but were always below the $0.100 \mathrm{mg} / \mathrm{L}$ regulatory limit. Since June 6, zinc has been below the detection limit in the effluent. Removal rates for zinc from mid-June to the present were calculated to be from $76 \%$ to $100 \%$, averaging $98 \%$. Lead was just at the detection limit or undetectable in all influent and effluent samples.

The metals results received to date for Tank 2 are shown in Table 3. The results showed that the APTsorb peat bed also operated effectively, reducing copper and zinc levels to below the new permit limits. The increase in flow from $1 \mathrm{gpm}$ to $2 \mathrm{gpm}$ during the study did not have a negative effect on effectiveness of the treatment. Before the addition of copper chloride to the influent, influent copper ranged from less than detectable $(<0.005 \mathrm{mg} / \mathrm{L})$ to $0.0115 \mathrm{mg} / \mathrm{L}$, exceeding the new permit limit on 5 days. After the addition of copper chloride to the influent water, incoming copper levels increased to as high as $0.048 \mathrm{mg} / \mathrm{L}$. As with Tank 1, copper in the effluent was below detectable in all samples. Using instrument readings when results were less than the detection limit, removal rates for copper from the second week of operation through September were calculated. Results ranged from $57 \%$ to $100 \%$, averaging $90 \%$, less than the $99 \%$ average removal achieved in Tank 1 . Zinc in the influent ranged from less than detectable $(<0.01 \mathrm{mg} / \mathrm{L})$ to $0.094 \mathrm{mg} / \mathrm{L}$, just keeping under the $0.100 \mathrm{mg} / \mathrm{L}$ permit limit. Zinc was measurable in the effluent samples during the first week of operation, but below the $0.100 \mathrm{mg} / \mathrm{L}$ regulatory limit. Since the second week of operation, zinc has been below the detection limit in the effluent except for the sample collected on September 5, which registered $0.0125 \mathrm{mg} / \mathrm{L}$, slightly above the detection limit. The September 5 sample was reanalyzed and the result was confirmed. Since this water sample was collected on the day after the peat and algae were collected from 


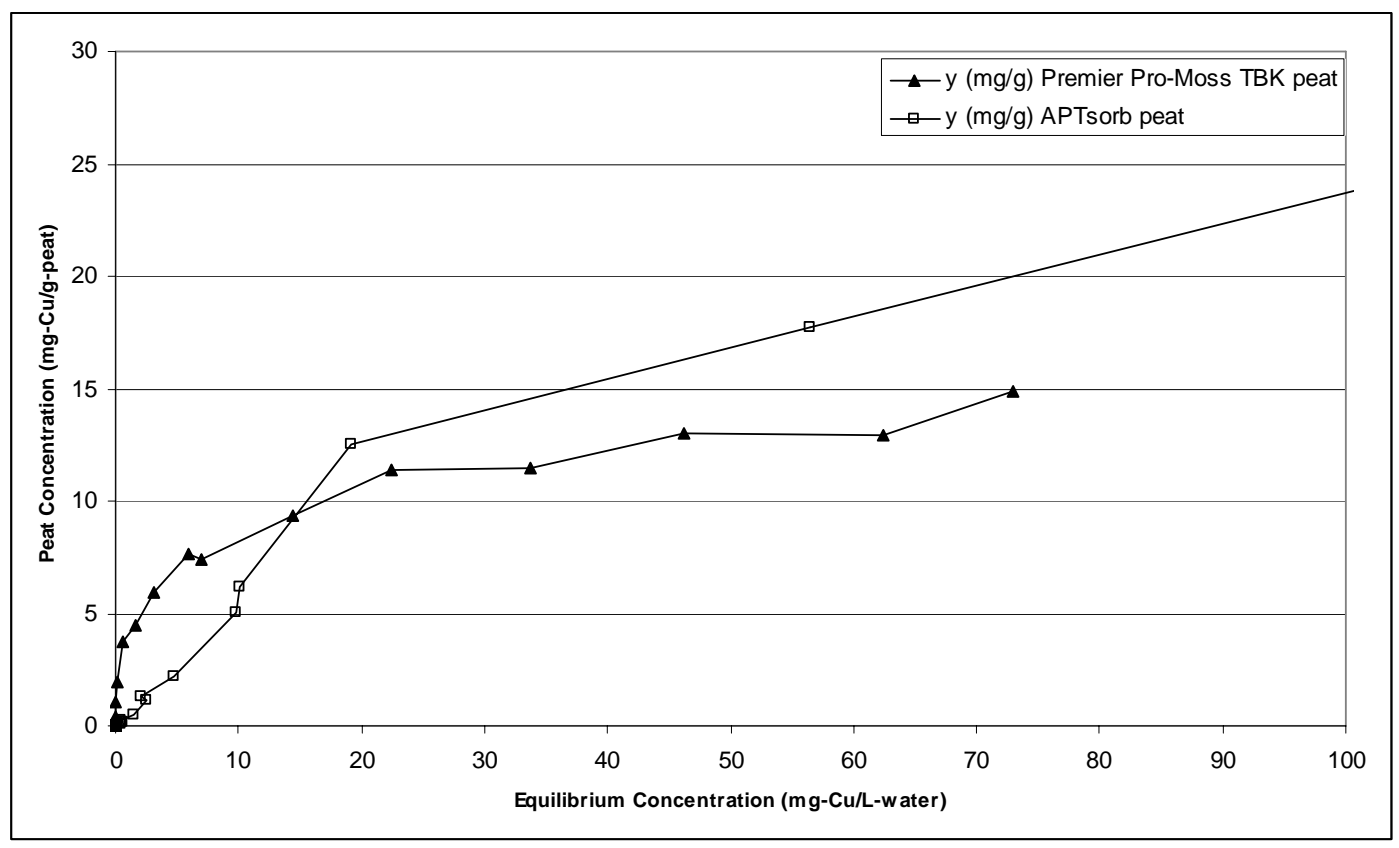

Figure 13. Peat adsorption isotherms of copper

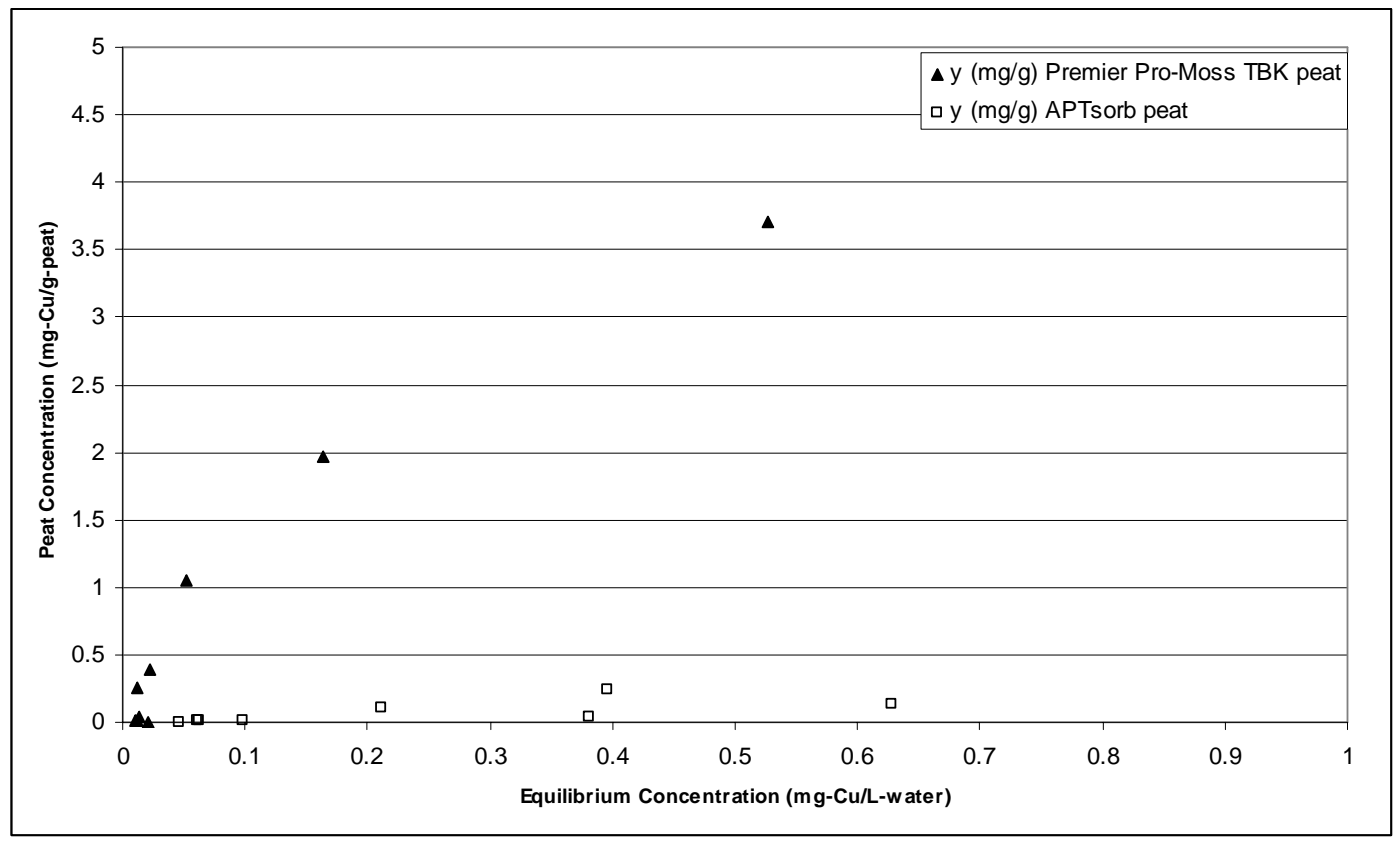

Figure 14. Peat adsorption isotherms of copper, low level $(<1 \mathrm{mg} / \mathrm{L})$ 
Table 2. TSS and Metals Results for Peat-Bed Pilot Study Tank 1

\begin{tabular}{|c|c|c|c|c|c|c|c|c|}
\hline Date & $\begin{array}{c}\text { Influent } \\
\text { TSS } \\
\text { (mg/l) } \\
\end{array}$ & $\begin{array}{c}\text { Effluent } \\
\text { TSS } \\
\text { (mg/l) } \\
\end{array}$ & $\begin{array}{c}\text { Influent Cu* } \\
(\mathrm{mg} / \mathrm{l})\end{array}$ & $\begin{array}{c}\text { Effluent Cu* } \\
(\mathrm{mg} / \mathrm{l})\end{array}$ & $\begin{array}{c}\text { Influent Pb* } \\
\text { (mg/l) }\end{array}$ & $\begin{array}{c}\text { Effluent Pb* } \\
\text { (mg/l) }\end{array}$ & $\begin{array}{c}\text { Influent Zn* } \\
(\mathrm{mg} / \mathrm{l})\end{array}$ & $\begin{array}{c}\text { Effluent Zn* } \\
\text { (mg/l) }\end{array}$ \\
\hline $6 / 4 / 07$ & 7 & 7 & $<0.005(0.0047)$ & $<0.005(0.0042)$ & $<0.002(0.0008)$ & $<0.002$ & 0.176 & 0.089 \\
\hline $6 / 5 / 07$ & 6 & 5 & 0.0055 & $<0.005$ (0.0018) & $<0.002$ & $<0.002$ & 0.17 & 0.044 \\
\hline 6/6/07 & $<1$ & 3 & $<0.005$ & $<0.005$ & $<0.002$ & $<0.002$ & 0.088 & $<0.01$ \\
\hline $6 / 7 / 07$ & 2 & 3 & $<0.005$ & $<0.005$ & $<0.002(0.0006)$ & $<0.002$ & 0.103 & $<0.01(0.0005)$ \\
\hline 6/8/07 & 5 & 2 & 0.0111 & $<0.005$ & $<0.002$ & $<0.002$ & 0.137 & $<0.01(0.0068)$ \\
\hline 6/11/07 & 1 & 3 & $<0.005(0.0034)$ & $<0.005(0.0006)$ & $<0.002(0.0000)$ & $<0.002(0.0017)$ & 0.1288 & $<0.01(0.0086)$ \\
\hline 6/14/07 & 3 & 1 & 0.015 & $<0.005(0.0014)$ & 0.002 & $<0.002(0.0004)$ & 0.132 & $<0.01(0.0096)$ \\
\hline 6/15/07 & 4 & 1 & 0.014 & $<0.005(0.0004)$ & $<0.002(0.0017)$ & 0.002 & 0.11 & $<0.01(0.0056)$ \\
\hline 6/18/07 & 5 & 1 & 0.006 & $<0.005(0.001)$ & $<0.002(0.0000)$ & $<0.002(0.0004)$ & 0.038 & $<0.01(0.0048)$ \\
\hline 6/19/07 & 1 & 1 & $<0.005(0.0022)$ & $<0.005$ & $<0.002$ & $<0.002$ & 0.0313 & $<0.01(0.0046)$ \\
\hline 6/20/07 & 1 & 2 & $\begin{array}{l}<0.005^{* *} \\
(0.0029)\end{array}$ & $<0.005(0.0000)$ & $<0.002 * *$ & $<0.002$ & $0.0413^{* *}$ & $<0.01(0.0031)$ \\
\hline 6/21/07 & 1 & 1 & $<0.005(0.0028)$ & $<0.005$ & $<0.002$ & $<0.002$ & 0.0475 & $<0.01(0.0033)$ \\
\hline $6 / 22 / 07$ & 1 & 2 & $<0.005$ & $<0.005$ & $<0.002$ & $<0.002$ & 0.0548 & $<0.01(0.0017)$ \\
\hline $6 / 25 / 07$ & 1 & 1 & $<0.005(0.0012)$ & $<0.005$ & $<0.002$ & $<0.002$ & 0.0169 & $<0.01(0.0001)$ \\
\hline $6 / 26 / 07$ & 3 & 1 & $<0.005$ (0.0013) & $<0.005$ & $<0.002$ & $<0.002$ & 0.0183 & $<0.01$ \\
\hline $6 / 27 / 07$ & 1 & 1 & 0.0069 & $<0.005$ & $<0.002$ & $<0.002(0.0006)$ & 0.078 & $<0.01$ \\
\hline 6/28/07 & 6 & 1 & 0.0059 & $<0.005$ & $<0.002$ & $<0.002$ & 0.0659 & $<0.01$ \\
\hline 6/29/07 & $5^{\dagger}$ & $1^{\dagger}$ & 0.0068 & $<0.005$ & $<0.002$ & $<0.002$ & 0.0656 & $<0.01$ \\
\hline 7/2/07 & 1 & 1 & $<0.005$ & $<0.005$ & $<0.002(0.0001)$ & $<0.002$ & 0.0393 & $<0.01$ \\
\hline 7/9/07 & 2 & 1 & 0.0174 & $<0.005$ & $<0.002$ & $<0.002$ & 0.0663 & $<0.01(0.0018)$ \\
\hline 7/16/07 & 2 & 3 & $<0.005$ & $<0.005$ & $<0.002$ & $<0.002$ & $<0.01(0.0036)$ & $<0.01$ \\
\hline $7 / 23 / 07$ & 1 & 1 & $<0.005(0.0026)$ & $<0.005(0.0001)$ & $<0.002(0.0017)$ & $<0.002(0.0006)$ & 0.0346 & $<0.01(0.0027)$ \\
\hline 7/30/07 & 3 & 1 & $<0.0005$ (0.0019) & $<0.005$ & $<0.002$ & $<0.002$ & 0.0461 & $<0.01$ \\
\hline 8/6/07 & 4 & 1 & 0.0062 & $<0.005$ & $<0.002$ & $<0.002$ & 0.0155 & $<0.01$ \\
\hline $8 / 13 / 07$ & $<1$ & $<1$ & $<0.005(0.0046)$ & $<0.005$ & $<0.002$ & $<0.002$ & 0.0249 & $<0.01$ \\
\hline
\end{tabular}


Table 2. TSS and Metals Results for Peat-Bed Pilot Study Tank 1 (cont.)

\begin{tabular}{|c|c|c|c|c|c|c|c|c|}
\hline Date & $\begin{array}{c}\text { Influent } \\
\text { TSS } \\
\text { (mg/l) }\end{array}$ & $\begin{array}{c}\text { Effluent } \\
\text { TSS } \\
\text { (mg/l) } \\
\end{array}$ & $\begin{array}{c}\text { Influent Cu* } \\
(\mathrm{mg} / \mathrm{l})\end{array}$ & $\begin{array}{c}\text { Effluent Cu* } \\
(\mathrm{mg} / \mathrm{l})\end{array}$ & $\begin{array}{c}\text { Influent Pb* } \\
(\mathrm{mg} / \mathrm{l})\end{array}$ & $\begin{array}{c}\text { Effluent Pb* } \\
(\mathrm{mg} / \mathrm{l})\end{array}$ & $\begin{array}{c}\text { Influent Zn* } \\
(\mathrm{mg} / \mathrm{l})\end{array}$ & $\begin{array}{c}\text { Effluent Zn* } \\
(\mathrm{mg} / \mathrm{l})\end{array}$ \\
\hline \multirow[t]{2}{*}{ 8/20/07 } & $<1$ & $<1$ & $<0.005(0.0018)$ & $<0.005$ & $<0.002$ & $<0.002(0.0008)$ & 0.0479 & $<0.01(0.0004)$ \\
\hline & & & & \multicolumn{2}{|c|}{ Copper addition system installed } & & & \\
\hline $8 / 22 / 07$ & --- & --- & 0.0492 & $<0.005(0.0002)$ & $<0.002(0.0018)$ & 0.002 & 0.0515 & $<0.01(0.0003)$ \\
\hline 8/23/07 & --- & --- & 0.0374 & $<0.005(0.0003)$ & 0.0026 & $<0.002(0.0013)$ & 0.0931 & $<0.01(0.0004)$ \\
\hline $8 / 27 / 07$ & 1 & 1 & 0.0374 & $<0.005(0.0005)$ & $<0.002(0.0008)$ & $<0.002(0.0013)$ & 0.0566 & $<0.01(0.0019)$ \\
\hline 8/29/07 & --- & --- & 0.0271 & $<0.005$ & $<0.002$ & $<0.002(0.0017)$ & 0.0391 & $<0.01$ \\
\hline 8/30/07 & --- & --- & 0.0186 & $<0.005$ & $<0.002(0.0017)$ & $<0.002$ (0.0009) & 0.0223 & $<0.01$ \\
\hline $9 / 4 / 07$ & 2 & 1 & 0.0185 & $<0.005(0.0002)$ & $<0.002$ & $<0.002$ & 0.0182 & $<0.01(0)$ \\
\hline 9/5/07 & --- & --- & 0.0201 & $<0.005(0.0002)$ & $<0.002(0.0008)$ & $<0.002(0.0003)$ & 0.0155 & $<0.01(0.0001)$ \\
\hline 9/6/07 & --- & --- & 0.0186 & $<0.005(0.0000)$ & $<0.002(0.0005)$ & $<0.002$ & 0.0174 & $<0.01$ \\
\hline 9/10/07 & 3 & $<1$ & $<0.005^{+\dagger}(0.0037)$ & $<0.005(0.0004)$ & $<0.002(0.0000)$ & $<0.002(0.0000)$ & 0.0165 & $<0.01(0.004)$ \\
\hline $9 / 12 / 07$ & --- & --- & 0.0122 & $<0.005(0.0005)$ & $<0.002$ & $<0.002$ & 0.0198 & $<0.01(0.0012)$ \\
\hline $9 / 13 / 07$ & --- & --- & 0.0136 & $<0.005(0.001)$ & $<0.002$ & $<0.002$ & 0.0337 & $<0.01(0.0016)$ \\
\hline 9/17/07 & 1 & 1 & 0.0103 & $<0.005(0.0004)$ & $<0.002$ & $<0.002$ & 0.094 & $<0.01(0.0013)$ \\
\hline
\end{tabular}

* Numbers in parentheses are instrument readings, though the results are below the practical quantitation limit (PQL). Other "less than” values in the table had negative instrument readings or no instrument readings available.

** Inlet samples on 6/20/07 had to be taken from the head of water in the tank because the pump stopped working just as the samplers arrived.

$\dagger \quad$ Samples exceeded hold times.

†† Copper addition system ran out of copper (II) chloride over the weekend. 
Table 3. TSS and Metals Results for Peat-Bed Pilot Study Tank 2

\begin{tabular}{|c|c|c|c|c|c|c|c|c|}
\hline Date & $\begin{array}{c}\text { Influent } \\
\text { TSS (mg/l) }\end{array}$ & $\begin{array}{c}\text { Effluent } \\
\text { TSS (mg/l) }\end{array}$ & $\begin{array}{c}\text { Influent Cu* } \\
\text { (mg/l) }\end{array}$ & $\begin{array}{c}\text { Effluent Cu* } \\
(\mathrm{mg} / \mathrm{l})\end{array}$ & $\begin{array}{c}\text { Influent Pb* } \\
\text { (mg/l) }\end{array}$ & $\begin{array}{c}\text { Effluent Pb* } \\
(\mathrm{mg} / \mathrm{l})\end{array}$ & $\begin{array}{c}\text { Influent Zn* } \\
\text { (mg/l) }\end{array}$ & $\begin{array}{c}\text { Effluent Zn* } \\
(\mathrm{mg} / \mathrm{l})\end{array}$ \\
\hline $7 / 10 / 07$ & $<1$ & 6 & $<0.005(0.0016)$ & $<0.005(0.0041)$ & $<0.002(0.0019)$ & 0.0029 & 0.0341 & 0.0171 \\
\hline 7/11/07 & $<1$ & 5 & $<0.005(0.0019)$ & $<0.005(0.0016)$ & 0.002 & $<0.002(0.0009)$ & 0.0416 & 0.0104 \\
\hline $7 / 16 / 07$ & 3 & 3 & $<0.005$ & $<0.005$ & $<0.002$ & $<0.002$ & $<0.01(0.0058)$ & $<0.01$ \\
\hline 7/17/07 & 3 & 3 & 0.0115 & $<0.005(0.0015)$ & $<0.002(0.0011)$ & $<0.002(0.0015)$ & 0.0572 & $<0.01(0.0044)$ \\
\hline $7 / 18 / 07$ & 1 & 2 & $<0.005(0.0034)$ & $<0.005(0.0007)$ & 0.0022 & $<0.002(0.0018)$ & 0.0108 & $<0.01(0.0035)$ \\
\hline 7/19/07 & 1 & 1 & $<0.005(0.003)$ & $<0.005$ (0.0008) & $<0.002(0.0015)$ & $<0.002(0.001)$ & 0.0175 & $<0.01(0.0032)$ \\
\hline 7/20/07 & 3 & 2 & 0.0082 & $<0.005(0.0011)$ & $<0.002(0.0011)$ & $<0.002(0.0008)$ & 0.0554 & $<0.01(0.0098)$ \\
\hline 7/23/07 & 1 & 1 & $<0.005(0.0024)$ & $<0.005(0.0007)$ & 0.0029 & $<0.002(0.0017)$ & 0.0345 & $<0.01(0.0031)$ \\
\hline $7 / 24 / 07$ & $<1$ & 1 & $<0.005(0.0037)$ & $<0.005(0.0016)$ & $<0.002(0.0008)$ & $<0.002(0.0012)$ & 0.0231 & $<0.01(0.0086)$ \\
\hline $7 / 25 / 07$ & 1 & 1 & 0.0063 & $<0.005(0.0007)$ & $<0.002$ & $<0.002$ & 0.0196 & $<0.01(0.0022)$ \\
\hline 7/26/07 & $<1$ & 1 & 0.0078 & $<0.005(0.0013)$ & $<0.002$ & $<0.002(0.0000)$ & 0.0154 & $<0.01(0.0023)$ \\
\hline 7/30/07 & 2 & 2 & $<0.005(0.0021)$ & $<0.005$ (0.0003) & $<0.002$ & $<0.002$ & 0.0463 & $<0.01$ \\
\hline 8/6/07 & 3 & 2 & 0.0070 & $<0.005$ (0.0006) & $<0.002$ & $<0.002$ & 0.0158 & 0.0011 \\
\hline 8/13/07 & $<1$ & $<1$ & $<0.005(0.0047)$ & $<0.005(0)$ & $<0.002$ & $<0.002$ & 0.0251 & $<0.01$ \\
\hline $8 / 20 / 07$ & $<1$ & $<1$ & $<0.005(0.0019)$ & $<0.005$ & $<0.002(0.0014)$ & $<0.002(0.0016)$ & 0.0485 & $<0.01(0.0012)$ \\
\hline & & & & \multicolumn{2}{|c|}{ Copper addition system installed } & ------------- & & \\
\hline $8 / 22 / 07$ & --- & --- & 0.0475 & $<0.005(0.0006)$ & $<0.002(0.0015)$ & $<0.002$ & 0.051 & $<0.01(0.0078)$ \\
\hline 8/23/07 & --- & --- & 0.0379 & $<0.005$ (0.0012) & 0.0033 & $<0.002(0.0010)$ & 0.0941 & $<0.01(0.0027)$ \\
\hline $8 / 27 / 07$ & 3 & $<1$ & 0.0292 & $<0.005(0.0009)$ & $<0.002(0.0003)$ & $<0.002(0.0015)$ & 0.0532 & $<0.01(0.0031)$ \\
\hline 8/29/07 & --- & --- & 0.0268 & $<0.005$ & $<0.002(0.0008)$ & $<0.002(0.0008)$ & 0.0383 & $<0.01$ \\
\hline 8/30/07 & --- & --- & 0.0185 & $<0.005$ & $<0.002$ & 0.0028 & 0.0212 & $<0.01(0.0000)$ \\
\hline $9 / 4 / 07$ & $<1$ & $<1$ & 0.0184 & $<0.005(0.0007)$ & $<0.002(0.0001)$ & $<0.002$ & 0.0181 & $<0.01(0.0013)$ \\
\hline $9 / 5 / 07$ & --- & --- & 0.0208 & $<0.005(0.0009)$ & $<0.002$ & $<0.002$ & 0.015 & 0.0125 \\
\hline $9 / 6 / 07$ & --- & --- & 0.019 & $<0.005(0.0008)$ & $<0.002$ & $<0.002(0.0002)$ & 0.0167 & $<0.01(0.0011)$ \\
\hline
\end{tabular}


Table 3. TSS and Metals Results for Peat-Bed Pilot Study Tank 2 (cont.)

\begin{tabular}{|c|c|c|c|c|c|c|c|c|}
\hline Date & $\begin{array}{c}\text { Influent } \\
\text { TSS (mg/l) } \\
\end{array}$ & $\begin{array}{c}\text { Effluent } \\
\text { TSS (mg/l) } \\
\end{array}$ & $\begin{array}{c}\text { Influent Cu* } \\
(\mathrm{mg} / \mathbf{l})\end{array}$ & $\begin{array}{c}\text { Effluent Cu* } \\
(\mathrm{mg} / \mathrm{l})\end{array}$ & $\begin{array}{c}\text { Influent Pb* } \\
\text { (mg/l) }\end{array}$ & $\begin{array}{c}\text { Effluent Pb* } \\
\text { (mg/l) }\end{array}$ & $\begin{array}{c}\text { Influent Zn* } \\
(\mathrm{mg} / \mathrm{l})\end{array}$ & $\begin{array}{c}\text { Effluent Zn* } \\
(\mathrm{mg} / \mathrm{l})\end{array}$ \\
\hline 9/10/07 & 1 & 1 & $<0.005^{\dagger}(0.0037)$ & $<0.005(0.0005)$ & $<0.002(0.0001)$ & $<0.002(0.0012)$ & 0.0167 & $<0.01(0.0017)$ \\
\hline 9/12/07 & --- & --- & 0.0125 & $<0.005(0.0007)$ & $<0.002$ & $<0.002$ & 0.0204 & $<0.01(0.0016)$ \\
\hline $9 / 13 / 07$ & --- & --- & 0.0264 & $<0.005(0.0007)$ & $<0.002$ & $<0.002(0)$ & 0.0356 & $<0.01(0.0017)$ \\
\hline 9/17/07 & $<1$ & $<1$ & 0.0101 & $<0.005(0.0006)$ & $<0.002$ & $<0.002(0.0002)$ & 0.0933 & $<0.01(0.0013)$ \\
\hline
\end{tabular}

* $\quad$ Numbers in parentheses are instrument readings, though the results are below the practical quantitation limit (PQL). Other "less than” values in the table had negative instrument readings or no instrument readings available

$\dagger \quad$ Copper addition system ran out of copper (II) chloride over the weekend. 
Tank 2, it is possible that the peat collection process stirred up the peat enough to cause a slight break-through. Removal rates for zinc from the second week of operation to the present ranged from $17 \%$ to $100 \%$, averaging $88 \%$, less than the 98\% removal achieved in Tank 1 . The low 17\% removal rate occurred on the date when the effluent zinc was above the detection limit. Lead ranged from less than detectable $(<0.02 \mathrm{mg} / \mathrm{L})$ to $0.033 \mathrm{mg} / \mathrm{L}$ in the influent and from less than detectable to $0.029 \mathrm{mg} / \mathrm{L}$ in effluent samples. The peat-bed treatment did not seem to have much effect on the lead concentrations.

TSS levels for Tank 1 have been similar to those seen at other NPDES outfalls onsite. Since the first few days of operation, when effluent TSS levels were somewhat elevated, TSS in the effluent has been generally lower and more stable than in the influent (Table 2). Peat fines do not appear to be passing out of the treatment system.

TSS levels for Tank 2 have been similar to those seen at other NPDES outfalls onsite. After the first few days of operation, TSS in the effluent was similar to that in the influent, and was generally low (Table 3). Peat fines do not appear to be passing out of the treatment system.

Influent and effluent $\mathrm{pH}$ measurements for Tank 1 are shown in Table 4. Influent $\mathrm{pH}$ varied widely from 4.61 to 8.85. As seen in the column study (Nelson and Specht, 2005), $\mathrm{pH}$ decreased as wastewater passed through the Tank 1 peat bed due to the cations in the influent water displacing hydrogen ions. Both the Tank 1 peat bed and the peat columns had initial discharges with a pH in the low 4s. The lowest effluent $\mathrm{pH}$ from Tank 1 was 4.14 on June 19. The column study results indicated that the $\mathrm{pH}$ would eventually stabilize between 5.5 and 6.0 (Nelson and Specht, 2005). The peat columns in the column study were run for more than 15 weeks, and the $\mathrm{pH}$ rose to 5.0 after approximately 4 weeks and stabilized between 5.5 and 6.0. Adjusting the amount of water treated in the column study for the additional copper that had been added $(1 \mathrm{mg} / \mathrm{l})$, which increased concentrations of cations available to displace hydrogen (Nelson 2007a), a calculation was performed indicating the pilot-scale peat bed might be expected to reach $\mathrm{pH}$ stabilization after treating approximately 270,000 gallons, which would be near the end of September, after about four months of operation. Since August 20, after eleven weeks of operation, the Tank 1 effluent has remained above the Outfall $\mathrm{H}-12$ permit lower limit of 4.8. At the time of this report, $\mathrm{pH}$ had risen to around 5.5 in Tank 1 effluent, but might not have reached full stabilization yet. In the event that a full scale peat bed is built for Outfall $\mathrm{H}-12$ using a peat moss similar to the Pro-Moss TBK, a temporary $\mathrm{pH}$ adjustment system might need to be provided for a few months while $\mathrm{pH}$ is stabilizing.

Influent and effluent $\mathrm{pH}$ measurements for Tank 2 are shown in Table 5. The $\mathrm{pH}$ in Tank 2 looked very different from Tank 1. The $\mathrm{pH}$ in the effluent was between 7 and 8 in all samples except for the first sample analyzed, showing much less variation than the influent $\mathrm{pH}$. The higher $\mathrm{pH}$ is expected to be the result of the calcium carbonate added to the peat moss during the manufacturing of the APTsorb peat.

Radiological screening results for Tank 1 influent and effluent are shown in Table 6. Water released to outfall H-12 has measurable radioactivity, but levels are low enough to be acceptable for environmental release. Gross beta results during this study were within historical values for that outfall. Gross alpha levels in the tank influent in a number of samples were higher than the historical monitoring data from the FM-1C and H-017 (281-8H retention basin discharge) sample locations. Two influent samples also exceeded the gross alpha bounding value (Table 6) used in determining the peat-bed facility hazard classification (Nelson 2007b), which was the higher of the two year averages of the monitoring data at the FM-1C and H-017 monitoring locations plus three standard deviations. However, the pilot-study gross alpha data were all well below the 281-8H retention basin gross alpha discharge limit of $3 \mathrm{dpm} / \mathrm{ml}$. The reason for the higher than expected gross alpha values has not been determined yet. The historical data is from 24-hour composite samples rather than grab samples, which can make direct comparison difficult.

Though not designed for the purpose of removing radionuclides, the peat did appear remove some of the radiological constituents from the influent water. Effluent gross alpha levels in Tank 1 were from $73 \%$ lower to essentially $100 \%$ lower (removed to below minimum detectable activity) than influent levels. Gross beta values in the Tank 1 effluent ranged from essentially 100\% lower (removed to below minimum detectable activity) to $79 \%$ higher than the influent. The apparent increase in gross beta on some dates could indicate that accumulated gross beta constituents were released from the peat bed, but was more likely to be caused by the variability in gross beta concentrations in the incoming water. Influent and effluent water samples were collected only a few minutes apart, so they represent slugs of water that were flowing to the outfall hours apart. The water concentrations could vary considerably during that time period. 
Table 4. pH Measurements for Peat-Bed Pilot Study Tank 1

\begin{tabular}{|c|c|c|}
\hline Date & Influent pH & Effluent pH \\
\hline $6 / 4 / 07$ & $6-7 *$ & $6-7 *$ \\
\hline $6 / 5 / 07$ & $8.85,8.5,8.66$ & $4.70,4.67,4.83$ \\
\hline $6 / 6 / 07$ & 6.42 & 4.96 \\
\hline $6 / 7 / 07$ & 6.81 & 4.76 \\
\hline $6 / 8 / 07$ & $5.84,6.00$ & $4.59,4.63$ \\
\hline $6 / 11 / 07$ & 5.83 & 4.71 \\
\hline 6/14/07 & 5.56 & 4.78 \\
\hline $6 / 15 / 07$ & 5.66 & 4.76 \\
\hline $6 / 18 / 07$ & 5.68 & 4.23 \\
\hline 6/19/07 & 5.83 & 4.14 \\
\hline $6 / 20 / 07$ & 5.45 & 4.36 \\
\hline $6 / 21 / 07$ & 6.22 & 4.35 \\
\hline $6 / 22 / 07$ & 5.82 & 4.23 \\
\hline $6 / 25 / 07$ & 6.74 & 4.54 \\
\hline $6 / 26 / 07$ & 6.72 & 4.52 \\
\hline $6 / 27 / 07$ & 6.32 & 4.47 \\
\hline 6/28/07 & 6.23 & 4.57 \\
\hline $6 / 29 / 07$ & 6.14 & 4.72 \\
\hline $7 / 2 / 07$ & 6.27 & 4.62 \\
\hline $7 / 9 / 07$ & 4.61 & 4.88 \\
\hline $7 / 16 / 07$ & 6.52 & 4.44 \\
\hline $7 / 17 / 07$ & 5.90 & 4.46 \\
\hline 7/18/07 & 6.60 & 4.34 \\
\hline 7/19/07 & 6.90 & 4.38 \\
\hline $7 / 20 / 07$ & NA & NA \\
\hline $7 / 23 / 07$ & 6.33 & 4.46 \\
\hline $7 / 24 / 07$ & 6.59 & 4.63 \\
\hline $7 / 25 / 07$ & 7.43 & 4.58 \\
\hline $7 / 26 / 07$ & 6.99 & 4.38 \\
\hline 7/30/07 & 6.16 & 4.41 \\
\hline $8 / 6 / 07$ & 7.00 & 4.54 \\
\hline $8 / 13 / 07$ & 6.39 & 4.79 \\
\hline $8 / 20 / 07$ & 6.35 & 4.88 \\
\hline $8 / 22 / 07$ & 6.29 & 4.95 \\
\hline $8 / 23 / 07$ & 5.82 & 4.91 \\
\hline $8 / 27 / 07$ & 6.13 & 4.89 \\
\hline $8 / 29 / 07$ & 5.43 & 5.08 \\
\hline $8 / 30 / 07$ & 5.84 & 4.93 \\
\hline $9 / 4 / 07$ & 6.67 & 5.05 \\
\hline $9 / 5 / 07$ & 6.73 & 5.14 \\
\hline $9 / 6 / 07$ & 6.83 & 5.36 \\
\hline 9/10/07 & 6.73 & 5.56 \\
\hline $9 / 11 / 07$ & 6.54 & 5.3 \\
\hline $9 / 12 / 07$ & 6.55 & 5.38 \\
\hline $9 / 17 / 07$ & 6.36 & 5.57 \\
\hline
\end{tabular}

* pH meter not functioning. $\mathrm{pH}$ measured with $\mathrm{pH}$ paper. Results are considered imprecise. 
Table 5. pH Measurements for Peat-Bed Pilot Study Tank 2

\begin{tabular}{ccc}
\hline Date & Influent $\mathbf{p H}$ & Effluent $\mathbf{p H}$ \\
\hline $7 / 10 / 07$ & 6.98 & 6.95 \\
$7 / 11 / 07$ & 6.66 & 7.08 \\
\hline $7 / 16 / 07$ & 7.39 & 7.16 \\
$7 / 17 / 07$ & 6.37 & 7.20 \\
$7 / 18 / 07$ & 6.69 & 7.10 \\
$7 / 19 / 07$ & 7.44 & 7.41 \\
\hline $7 / 23 / 07$ & 6.69 & 7.23 \\
$7 / 24 / 07$ & 7.40 & 7.36 \\
$7 / 25 / 07$ & 7.45 & 7.39 \\
$7 / 26 / 07$ & 7.65 & 7.48 \\
$7 / 27 / 07$ & $\mathrm{NA}$ & $\mathrm{NA}$ \\
\hline $7 / 30 / 07$ & 7.15 & 7.35 \\
\hline $8 / 6 / 07$ & 7.27 & 7.42 \\
\hline $8 / 13 / 07$ & 7.32 & 7.21 \\
\hline $8 / 20 / 07$ & 6.54 & 7.44 \\
$8 / 22 / 07$ & 6.45 & 7.45 \\
$8 / 23 / 07$ & 6.46 & 7.42 \\
\hline $8 / 27 / 07$ & 6.86 & 7.37 \\
$8 / 29 / 07$ & 5.59 & 7.29 \\
$8 / 30 / 07$ & 6.02 & 7.44 \\
\hline $9 / 4 / 07$ & 6.45 & 7.45 \\
$9 / 5 / 07$ & 7.03 & 7.48 \\
$9 / 6 / 07$ & 7.13 & 7.63 \\
\hline $9 / 10 / 07$ & 7.40 & 7.71 \\
$9 / 12 / 07$ & 7.21 & 7.44 \\
$9 / 13 / 07$ & 6.70 & 7.50 \\
\hline $9 / 17 / 07$ & 6.50 & 7.66 \\
\hline
\end{tabular}

Table 6. Radiological Screening Results for Tank 1 Water Samples

\begin{tabular}{ccccccc}
\hline Date & $\begin{array}{c}\text { Influent H-3 } \\
\text { (pCi/ml) }\end{array}$ & $\begin{array}{c}\text { Effluent H-3 } \\
\text { (pCi/ml) }\end{array}$ & $\begin{array}{c}\text { Influent } \\
\text { Gross Alpha } \\
\text { (dpm/ml) }\end{array}$ & $\begin{array}{c}\text { Effluent } \\
\text { Gross Alpha } \\
\text { (dpm/ml) }\end{array}$ & $\begin{array}{c}\text { Influent } \\
\text { Gross Beta } \\
\text { (dpm/ml) }\end{array}$ & $\begin{array}{c}\text { Effluent } \\
\text { Gross Beta } \\
\text { (dpm/ml) }\end{array}$ \\
\hline $6 / 14 / 07$ & $2.62 \mathrm{E}+00$ & $3.77 \mathrm{E}+00$ & $1.94 \mathrm{E}-02$ & $4.65 \mathrm{E}-03$ & $1.27 \mathrm{E}-01$ & $\mathrm{ND}$ \\
$6 / 27 / 07$ & $2.25 \mathrm{E}+00$ & $4.40 \mathrm{E}+00$ & $1.42 \mathrm{E}-02$ & $3.03 \mathrm{E}-03$ & $1.06 \mathrm{E}-01$ & $1.12 \mathrm{E}-02$ \\
$7 / 9 / 07$ & $7.17 \mathrm{E}-01$ & $1.70 \mathrm{E}+00$ & $5.13 \mathrm{E}-02$ & $\mathrm{ND}$ & $3.44 \mathrm{E}-02$ & $7.75 \mathrm{E}-03$ \\
$7 / 23 / 07$ & $3.98 \mathrm{E}+00$ & $4.33 \mathrm{E}+00$ & $9.97 \mathrm{E}-03$ & $\mathrm{ND}$ & $8.37 \mathrm{E}-03$ & $1.50 \mathrm{E}-02$ \\
$8 / 6 / 07$ & $7.19 \mathrm{E}+00$ & $5.91 \mathrm{E}+00$ & $5.99 \mathrm{E}-03$ & $\mathrm{ND}$ & $6.00 \mathrm{E}-03$ & $6.65 \mathrm{E}-03$ \\
$8 / 20 / 07$ & $1.29 \mathrm{E}+00$ & $1.59 \mathrm{E}+00$ & $9.97 \mathrm{E}-03$ & $\mathrm{ND}$ & $1.00 \mathrm{E}-02$ & $9.65 \mathrm{E}-03$ \\
$9 / 4 / 07$ & $2.43 \mathrm{E}+00$ & $1.55 \mathrm{E}+00$ & $6.07 \mathrm{E}-03$ & $\mathrm{ND}$ & ND & $1.43 \mathrm{E}-02$ \\
$9 / 17 / 07$ & $1.97 \mathrm{E}+00$ & $2.01 \mathrm{E}+00$ & $7.61 \mathrm{E}-03$ & ND & $1.46 \mathrm{E}-02$ & ND \\
\hline Mean* & $2.81 \mathrm{E}+00$ & $3.16 \mathrm{E}+00$ & $1.56 \mathrm{E}-02$ & $1.47 \mathrm{E}-03$ & $3.88 \mathrm{E}-02$ & $8.48 \mathrm{E}-03$ \\
\hline Bounding & $1.26 \mathrm{E}+04$ & --- & $1.43 \mathrm{E}-02$ & & & \\
Value** & & & & & & \\
\hline
\end{tabular}

* Means were calculated using instrument values rather than zeros for non-detects.

** Value used in calculating potential facility hazard category, using a two year average plus three standard deviations (Nelson 2007b).

ND - Non-detectable; value reported was less than the minimum detectable limit. 
Radiological screening results for Tank 2 influent and effluent are shown in Table 7. Gross alpha and beta results for the influent were generally within historical values for that outfall. Gross alpha levels were $13 \%$ to $100 \%$ lower in the effluent than in the influent, demonstrating the peat's capability to removal some of the radiological constituents. The APTsorb peat did not appear to be as effective at removing gross alpha as the Premier peat, but as mentioned previously, the apparent lack of removal in some samples may simply have been the result of the timing of collecting the effluent sample vs. the influent sample. Gross beta values in the effluent ranged from 19\% to essentially $100 \%$ lower (removed to below minimum detectable activity) than the influent.

Table 7. Radiological Screening Results for Tank 2 Water Samples

\begin{tabular}{ccccccc}
\hline Date & $\begin{array}{c}\text { Influent H-3 } \\
\text { (pCi/ml) }\end{array}$ & $\begin{array}{c}\text { Effluent H-3 } \\
\text { (pCi/ml) }\end{array}$ & $\begin{array}{c}\text { Influent } \\
\text { Gross Alpha } \\
\text { (dpm/ml) }\end{array}$ & $\begin{array}{c}\text { Effluent } \\
\text { Gross Alpha } \\
\text { (dpm/ml) }\end{array}$ & $\begin{array}{c}\text { Influent } \\
\text { Gross Beta } \\
\text { (dpm/ml) }\end{array}$ & $\begin{array}{c}\text { Effluent } \\
\text { Gross Beta } \\
\text { (dpm/ml) }\end{array}$ \\
\hline $7 / 18 / 07$ & $1.29 \mathrm{E}+00$ & $1.36 \mathrm{E}+00$ & $5.59 \mathrm{E}-03$ & $\mathrm{ND}$ & $\mathrm{ND}$ & $\mathrm{ND}$ \\
$8 / 6 / 07$ & $7.28 \mathrm{E}+00$ & $6.61 \mathrm{E}+00$ & $4.70 \mathrm{E}-03$ & $4.11 \mathrm{E}-03$ & $5.73 \mathrm{E}-03$ & $3.95 \mathrm{E}-03$ \\
$8 / 20 / 07$ & $1.03 \mathrm{E}+00$ & $1.69 \mathrm{E}+00$ & $9.86 \mathrm{E}-03$ & $\mathrm{ND}$ & $8.04 \mathrm{E}-03$ & $\mathrm{ND}$ \\
$9 / 4 / 07$ & $2.59 \mathrm{E}+00$ & $1.84 \mathrm{E}+00$ & $4.93 \mathrm{E}-03$ & $\mathrm{ND}$ & $7.49 \mathrm{E}-03$ & $6.10 \mathrm{E}-03$ \\
$9 / 17 / 07$ & $1.48 \mathrm{E}+00$ & $2.00 \mathrm{E}+00$ & $\mathrm{ND}$ & $\mathrm{ND}$ & $1.25 \mathrm{E}-02$ & $7.22 \mathrm{E}-03$ \\
\hline Mean* & $2.73 \mathrm{E}+00$ & $2.70 \mathrm{E}+00$ & $5.61 \mathrm{E}-03$ & $1.01 \mathrm{E}-03$ & $6.74 \mathrm{E}-03$ & $3.78 \mathrm{E}-03$ \\
\hline Bounding & $1.26 \mathrm{E}+04$ & --- & $1.43 \mathrm{E}-02$ & -- & $8.94 \mathrm{E}-01$ & - \\
Value** & & & & & & - \\
\hline
\end{tabular}

* Means were calculated using instrument values rather than zeros for non-detects.

** Value used in calculating potential facility hazard category, using a two year average plus three standard deviations (Nelson 2007b).

ND - Non-detectable; value reported was less than the minimum detectable limit.

Transducer measurements in Tank 1 showed that the tank water level had been exhibiting a diurnal swing (Figure 15). Water levels reached a high point each day between 8:00 and 11:00 AM and dropped to a low point between about 3:00 and 7:00 PM, at which time the level would begin to rise again. The inception date of this phenomenon is not certain because the transducers were not installed until the water level variation had been noticed. However, the transducer in Tank 2 was installed before any tank water level variation was visually noted in that tank. Review of the data for Tank 2 showed a similar variation of the water levels, on a much smaller scale and with slightly different peak times. Over time, however, the water level vacillation in Tank 2 appeared to increase, perhaps with the growth of algae on the surface of the substrate (Figure 15). Various explanations have been hypothesized, including expansion of the tank during the heat of the day (which could allow water to short-circuit along the side of the tank), increased activity by the algae, or clogging of the top layer of the peat. The exact cause has not been determined. Design of a full scale peat bed system for Outfall H-12 would need to incorporate sufficient freeboard in the peat beds to account for the daily swing in water levels.

A schematic showing the monitoring ports and material layers in Tank 1 is shown in Figure 16 . A YSI ${ }^{\circledR}$ multiparameter water quality meter was used to measure the water quality indicators, $\mathrm{pH}$, specific conductance, and dissolved oxygen, at different depths in the tank using the monitoring ports. Measurements were made in early June, shortly after Tank 1 began operating, and in September, after three months of operation. Results are shown in Figures 17 through 19. Initially, $\mathrm{pH}$ decreased within Tank 1; however, by September the $\mathrm{pH}$ was essentially unchanged with depth (Figure 17). This is the result of the depletion of $\mathrm{H}^{+}$ions initially sorbed onto the peat that were desorbed by water treated during the preceding portion of the pilot study. The specific conductivity profile for June (Figure 18) shows an increase with depth in the peat indicating that the water may have dissolved a slight amount of material in the peat. The specific conductivity is similar from top to bottom in the September profile suggesting the amount of dissolved material in the water is unchanged through the depth of the bed. Dissolved oxygen decreased with depth in both profiles due to the reducing environment that existed in the peat (Figure 19). 


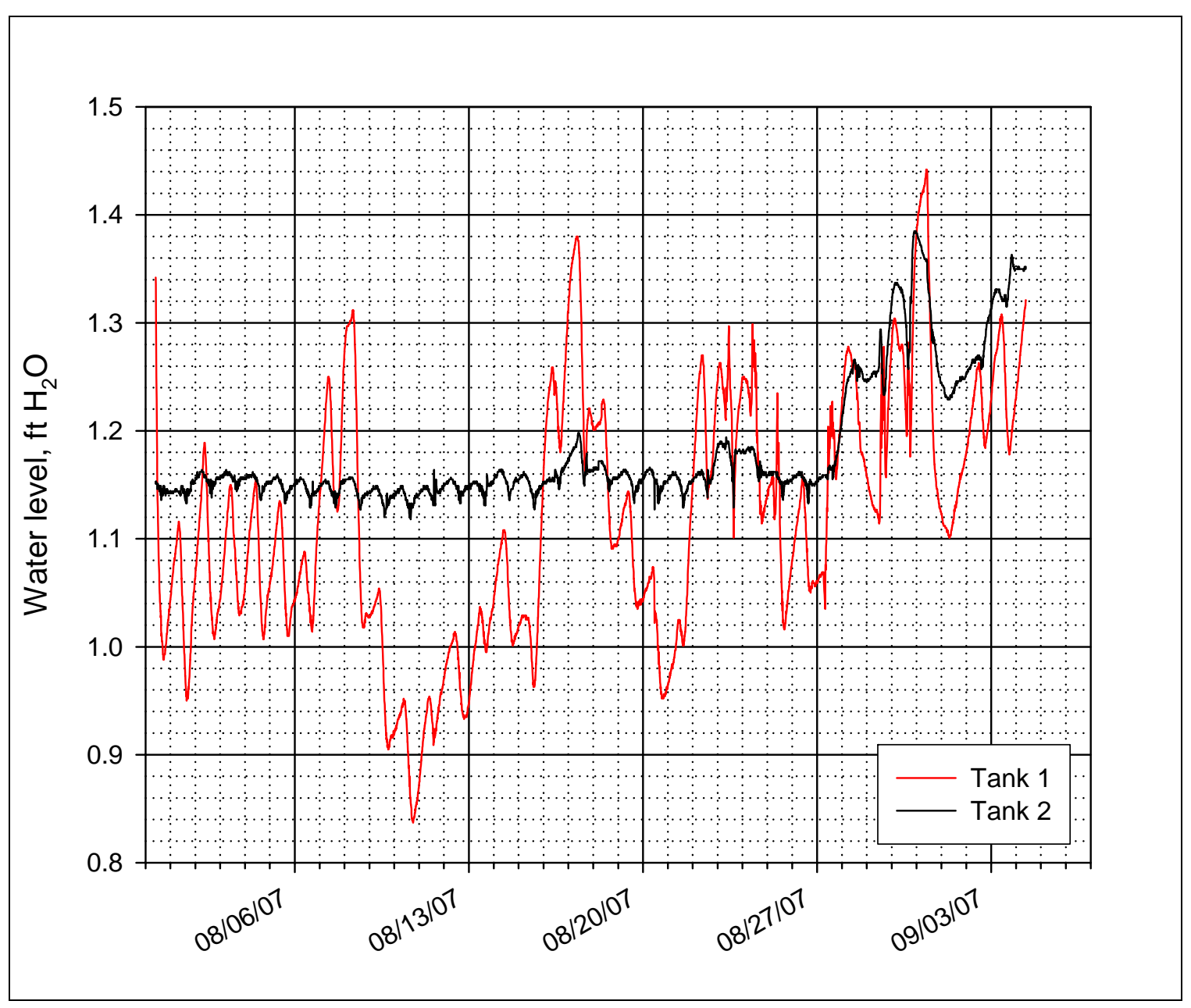

Figure 15. Water levels in Tanks 1 and 2 


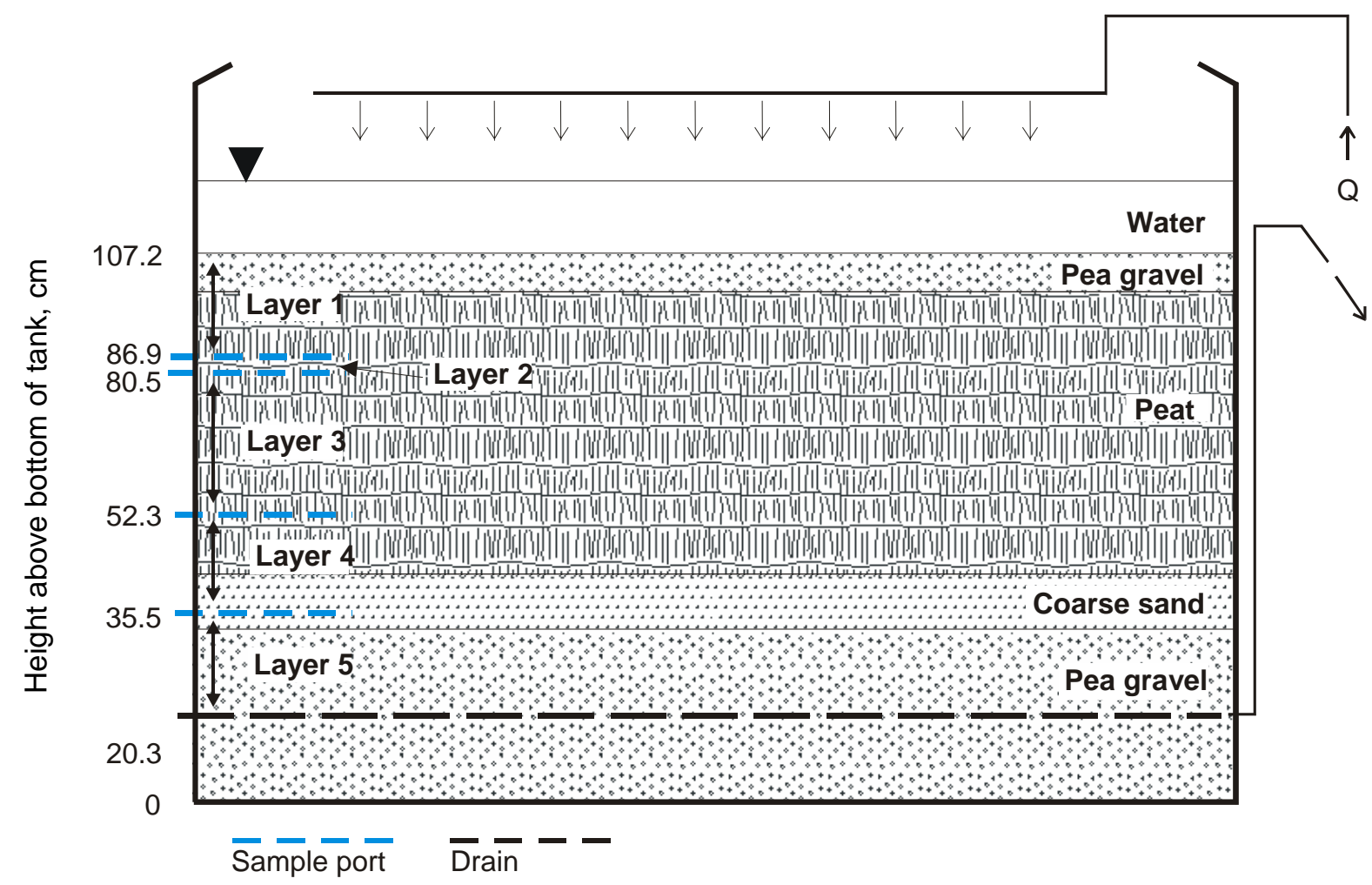

Figure 16. Monitoring points and material layers in Tank 1

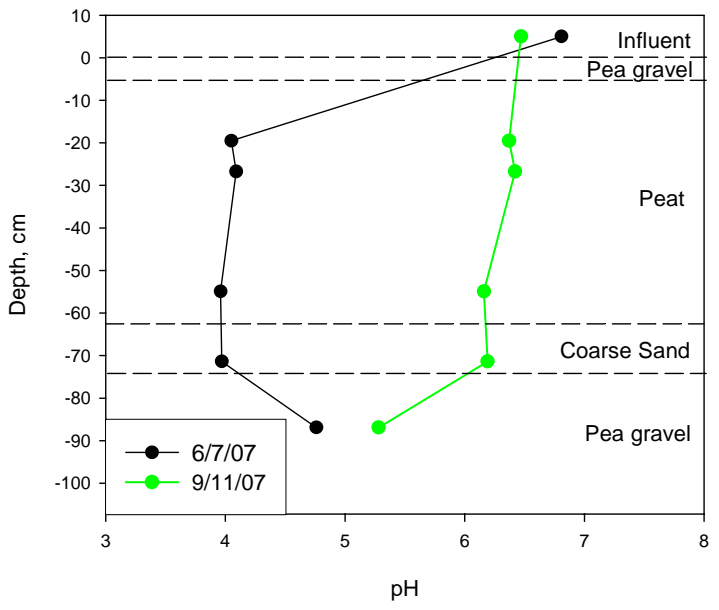

Figure 17. $\mathrm{pH}$ at various depths in Tank 1

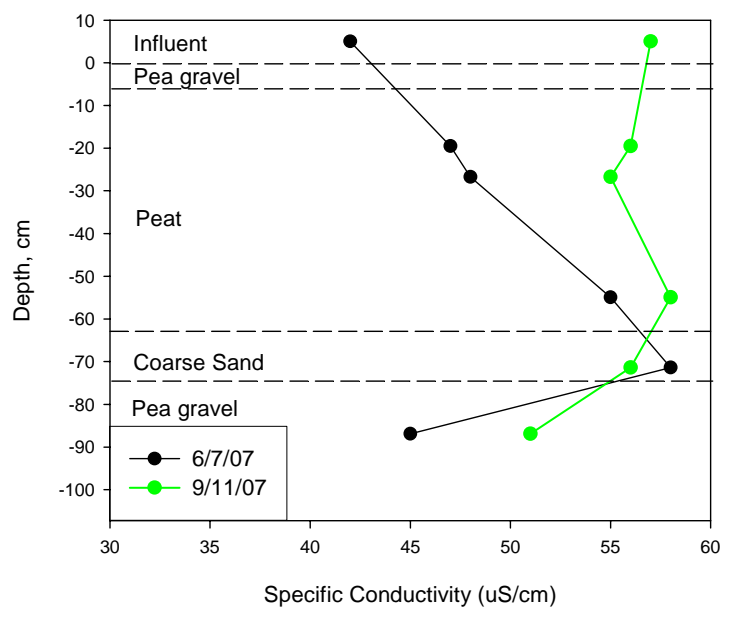

Figure 18. Specific conductivity at various depths in Tank 1 


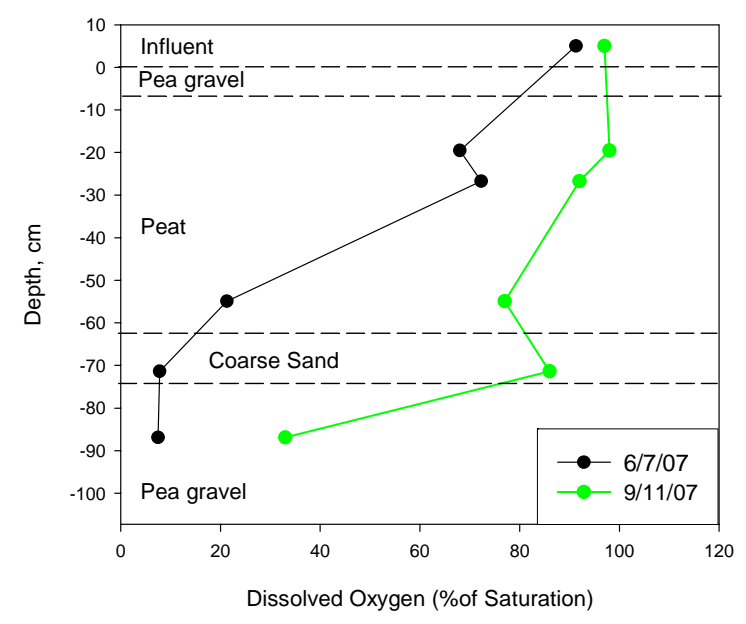

Figure 19. Dissolved oxygen at various depths in Tank 1

Hydraulic head was measured using the sample ports in Tank 1 (Figure 16). Using this data, the hydraulic conductivity of the peat-bed treatment system was calculated using Darcy's law for fluid flow in porous media. Darcy's law can be written as shown in equation 1 to calculate hydraulic conductivity. In this study the flow rate was measured using a flow meter on the inlet side of the peat-bed tank and hydraulic head was measured at several depths in the system.

$$
\begin{aligned}
& \qquad K=\frac{Q}{(\Delta h / \Delta l) * A} \text { (1) } \\
& K=\text { hydraulic conductivi ty, } \mathrm{cm} / \mathrm{sec} \\
& Q=\text { flowrate }, \mathrm{cm}^{3} / \mathrm{sec} \\
& \Delta h=\text { head difference }, \mathrm{cm} \\
& \Delta l=\text { length }, \mathrm{cm} \\
& A=\text { cross sec tional area }, \mathrm{cm}^{2}
\end{aligned}
$$

Hydraulic conductivity of the system and individual layers was measured three times during the study. Table 8 contains the results of the individual hydraulic conductivity measurements. The equivalent hydraulic conductivity for vertical flow through a series of horizontal layers can be calculated using Equation 2. The results for individual layers were used to estimate the system hydraulic conductivity (Table 8) as a check on the data and method used to measure hydraulic conductivity. The results show good agreement between the two methods for determining system hydraulic conductivity.

$$
K_{z}=\frac{d}{\sum_{i=1}^{n} d_{i} / K_{i}}
$$

$K_{z}=$ equivalent (system) hydraulic conducivit $y, \mathrm{~cm} / \mathrm{sec}$

$d=$ system thickness, $\mathrm{cm}$

$d_{i}=$ layer thickness, $\mathrm{cm}$

$K_{i}=$ layer hydraulic conductivi ty, $\mathrm{cm} / \mathrm{sec}$ 
Table 8. Results from hydraulic conductivity measurements at Tank 1

\begin{tabular}{lccc}
\hline & \multicolumn{3}{c}{ Hydraulic Conductivity, cm/sec } \\
\cline { 2 - 4 } Interval* & $\mathbf{6 / 2 9 / 0 7}$ & $\mathbf{8 / 6 / 0 7}$ & $\mathbf{9 / 1 0 / 0 7}$ \\
\hline System (measured) & 0.084 & 0.0102 & 0.0061 \\
Layer 1 & $\mathrm{nm}$ & 0.0118 & 0.0075 \\
Layer 2 & $\mathrm{nm}$ & 0.0022 & 0.0211 \\
Layer 3 & $\mathrm{nm}$ & 0.0548 & 0.0048 \\
Layer 4 & $\mathrm{nm}$ & 0.0084 & 0.0066 \\
Layer 5 & $\mathrm{nm}$ & 0.0110 & 0.0053 \\
System (calculated) & --- & 0.0095 & 0.0056 \\
\hline
\end{tabular}

- Layers are shown in Figure 16

- $\mathrm{nm}=$ not measured

Hydraulic conductivity measurements made during this study are comparable to measurements from other studies (Table 9). Hydraulic conductivity measurements in peat can very widely. As expected, the hydraulic conductivities measured in this study were on the higher end of the range of values and were similar to hydraulic conductivities measured in other processed peat samples (Shibchurn et al. 2005) and at shallow depths in peat cores (Rizzuti et al. 2004, Hoag and Price 1997).

Table 9. Comparison with hydraulic conductivity values in other studies

\begin{tabular}{lccc}
\hline & & \multicolumn{2}{c}{ Range of Hydraulic Conductivity (cm/sec) } \\
\cline { 3 - 4 } Study & Setting & High & Low \\
\hline Outfall H-12 Pilot Study & Processed peat, uncompacted & $8.40 \mathrm{E}-02$ & $2.20 \mathrm{E}-03$ \\
Rizzuti et al. 2004 & Cores collected at SRS & $3.90 \mathrm{E}-03$ & $2.60 \mathrm{E}-05$ \\
Hoag and Price 1997 & Cores collected in Newfoundland & $3.30 \mathrm{E}-03$ & $1.00 \mathrm{E}-04$ \\
Baird and Gaffney 2000 & In-situ measurements in the UK & $6.31 \mathrm{E}-04$ & $6.00 \mathrm{E}-05$ \\
Shibchurn et al. 2005 & Milled peat for use in a biofilter & $1.38 \mathrm{E}-01$ & $8.50 \mathrm{E}-03$ \\
\hline
\end{tabular}

The peat-bed system hydraulic conductivity decreased over time from $0.084 \mathrm{~cm} / \mathrm{sec}$ to $0.0061 \mathrm{~cm} / \mathrm{sec}$ (Table 8). The decline in hydraulic conductivity might have been due to the following:

- Swelling of the peat due to hydration

- Retention and subsequent growth of biomass (algae) residue pumped into the tank from Outfall H-12

- Growth of microorganisms in peat. Microorganism growth would be sustained by carbohydrates, organic acids, and fixed nitrogen excreted by algae growing on the surface of the peat-bed.

Decreased hydraulic conductivity will result in a greater head loss though the system, producing increased water levels above the peat surface. Water level and flow data collected during the pilot test were consistent with this observation. Figure 20 shows the water level and flow trends for five weeks beginning July 31, 2007. The water level rose $\sim 0.2$ feet during this monitoring period, even though there was a decrease in the flow rate which should have resulted in a lower water level in the tank. Regression analysis of the water level data indicated that the water level in the tank was increasing $\sim 0.0058 \mathrm{ft} /$ day.

The possibility of algae eventually causing clogging of the full-scale peat bed had been a concern in the design of the full-scale system. The algae itself could cause a problem, but a greater concern would be the growth of bacteria in the upper layers of the peat. The algae would generate a carbon food-source in the upper layer of peat, fueling the growth of the bacteria. Microorganisms could clog pores in the peat and decrease its hydraulic conductivity and permeability.

Algae began to be noticed in the tanks after several weeks of operation. Algae can be introduced to a pool by rainwater or wind. However, the major source of the algae in the peat-bed tanks was believed to be the water discharged from the $281-8 \mathrm{H}$ retention basin. The $281-8 \mathrm{H}$ retention basin was known to have algae problems. During some of the days when the $281-8 \mathrm{H}$ basin was discharging to Outfall $\mathrm{H}-12$, the influent water pooled in the peat bed tanks was turbid enough that the top of the substrate could not be seen. 


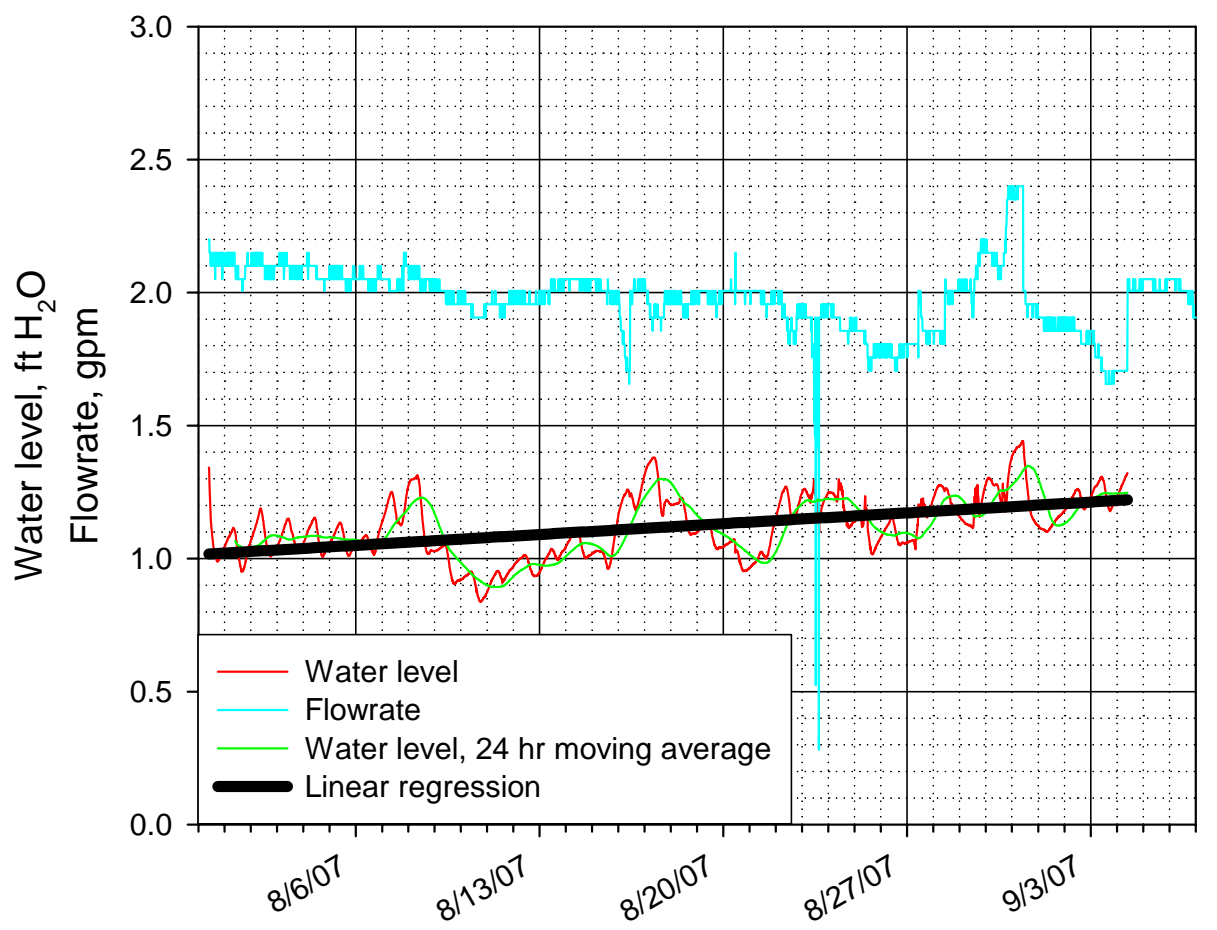

Figure 20. Water level and flow rate trends for Tank 1

The algae growing in Tank 1 appeared to be different from that growing in Tank 2. The algae on the substrate of Tank 1 were green and covered with bubbles of the gas it generated (Figure 21). The algae floated to the surface if knocked loose from the gravel. The algae in Tank 2 did not appear as bright, and seemed to form a "crust" on the surface of the peat. Figure 22 shows the surface of the peat in Tank 2 in a location where a peat sample was collected, disturbing the "crust" of algae on top of the peat. Algae also were growing on the sides of both tanks and even on the surface of the LG Sonic SSS mounting structure, though not on the surface of the ultrasonic transducer, itself, indicating that the transducer was working to some degree.

Ultrasonic devices control algae by emitting an underwater ultrasonic wave that causes the vacuoles in the algae to resonate and rupture. A device's effectiveness varies depending on the type of algae present. Product literature indicated that some algae may take several weeks to die off (LG Sound 2007) and another source (Canadianpond.ca Products Limited 2007) indicated some types of algae are not susceptible to the ultrasonic vibrations. The ultrasonic algae controller installed in Tank 1 had not caused noticeable reduction in the algae growing on top of the gravel layer or on walls of the tank at the time of this report. However, there were less algae floating on the top of Tank 1 than Tank 2 after about four weeks of operation of the LG Sonic SSS.

Algae samples were collected on September 4 from both tanks. SRNL Environmental Biotechnology Section personnel evaluated the samples. In both tanks, the growth was a thick gelatinous biofilm containing a variety of organisms, including small rotifers, paramecium, green algae, cyanobacteria and many other bacteria typical of "pond scum" (Yeager 2007). There was an abundance of an as-yet unidentified green algae, as well as a Leptolyngbya-type species in the Oscillatoriales group of cyanobacteria. The Leptolyngbya-type algae might have been the major, but not only, generator of the biofilm, which provided a favorable habitat for growth of other microorganisms. Such a biofilm could clog the peat and hinder flow through the peat bed. The ultrasonic wave technology is not expected to kill Oscillatoria (Canadianpond.ca Products Limited 2007). The biofilm the Oscillatoria generates may also protect other algal species from the ultrasonic waves (Yeager 2007). 


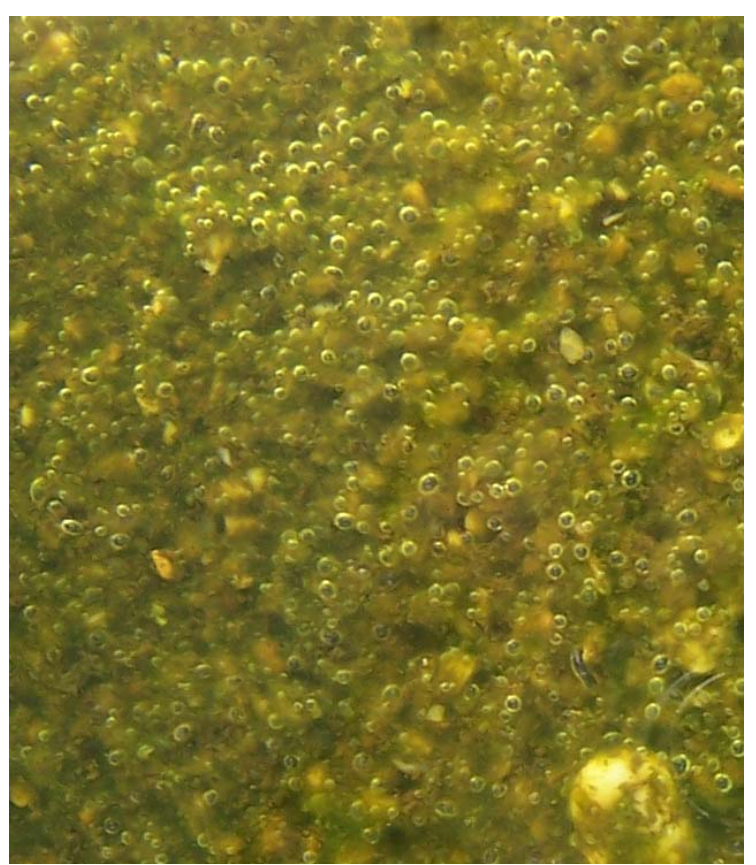

Figure 21. Algae growing on the gravel surface in Tank 1

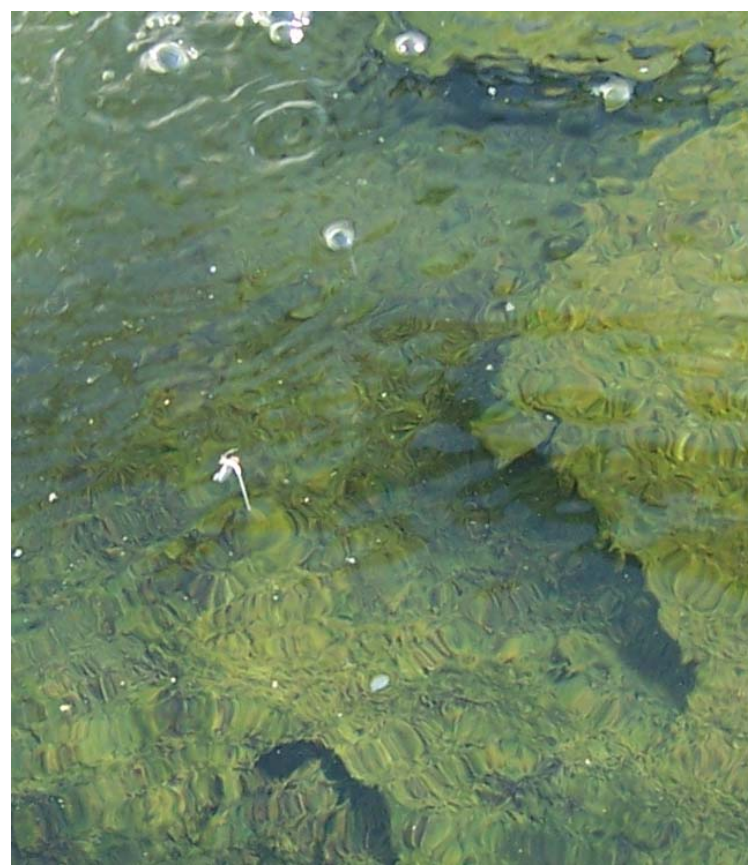

Figure 22. Algae growing on the peat in Tank 2 where the surface was disturbed

To prevent algae/bacteria problems in the full-scale peat bed, algae must be controlled in the various upstream retention basins that are exposed to sunlight, such as the $281-8 \mathrm{H}$ and $241-103 \mathrm{H}$ basins, in addition to the peat beds, themselves. Long-term operation of ultrasonic devices could be a part of the algae control solution, but some sort of ultraviolet light blocking mechanism on the peat beds is strongly recommended to prevent the bacterial growth that can clog the peat pores. A floating cover or a layer of small floating balls would reduce the ultraviolet light and minimize the algae and bacteria growth.

\section{Summary and Recommendations}

The results of the Outfall H-12 peat-bed pilot study supported the results of earlier laboratory studies. The peat media proved to be highly effective in removing copper and zinc from Outfall H-12 effluent to below the detection limits regardless of variations in influent concentrations and $\mathrm{pH}$. Both types of peat tested removed the copper and zinc to below detection limits ( $0.005 \mathrm{mg} / \mathrm{L}$ for copper and $0.01 \mathrm{mg} / \mathrm{L}$ for zinc), but the Premier Pro-Moss TBK peat performed better than the APTsorb peat for both copper and zinc removal, as expected based on the bench scale study that showed that loading of copper onto the Premier peat was higher compared with the APTsorb peat when the source water contained copper concentrations similar to that found at Outfall H-12. In the pilot study, the ProMoss TBK removed an average of $99 \%$ of the incoming copper and $98 \%$ of the incoming zinc. The APTsorb peat removed an average $90 \%$ and $88 \%$ of the incoming copper and zinc, respectively.

Peat bed technology would be a suitable solution for treating copper, zinc, and perhaps other metal constituents at Outfall H-12 or other site outfalls if the issues of temporarily low effluent $\mathrm{pH}$ and prevention of algae are addressed in system design. Upon start-up of a new peat bed, low $\mathrm{pH}$ would be a problem for a few months until a sufficient volume of water has been treated by the peat, unless a pretreated peat like the APTsorb is used. For this pilot study, calculations indicated that the Premier-type peat would need to treat about 270,000 gallons to reach $\mathrm{pH}$ stabilization (between 5.5 and 6.0), which would occur near the end of September, after four months of operation. As of September 17, the $\mathrm{pH}$ in Tank 1 of the pilot study had risen from a low of 4.14 on June 19 to over 5.5 and had been above the outfall's lower limit of 4.8 for several weeks. Should the peat-bed technology be implemented, a $\mathrm{pH}$ adjustment system would need to be provided and operated temporarily until the $\mathrm{pH}$ stabilizes. 
Prevention of algal/bacterial growth in the peat-bed would be important for controlling water levels and maintaining adequate hydraulic conductivity in the peat. Algal/bacterial growth became noticeable in the pilot study tanks after a few weeks of operation. As of the preparation of this report, the ultrasonic device installed to kill the algae in Tank 1 had not been very effective. In both tanks, the growth was a thick gelatinous biofilm containing a variety of organisms typical of "pond scum". An abundance of a Leptolyngbya-type species in the Oscillatoriales group of cyanobacteria might have been the major, but not only, generator of the biofilm, which provided a favorable habitat for growth of other microorganisms (Yeager 2007). Such a biofilm can clog the peat and hinder flow through the peat bed. The ultrasonic wave technology is not expected to kill Oscillatoria (Canadianpond.ca Products Limited 2007). In addition, the biofilm the Oscillatoria algae generate may protect other algal species from the ultrasonic waves (Yeager 2007).

To prevent algae problems in the full-scale peat bed, algae must be controlled in the various upstream retention basins that are exposed to sunlight, such as the 281-8H and 241-103H basins. Long-term operation of ultrasonic devices could be a part of the algae control solution, but some sort of ultraviolet light blocking mechanism on the peat beds is strongly recommended to better prevent the algal/bacterial/biofilm growth that can clog the peat pores. A floating cover or a layer of small floating balls would reduce the ultraviolet light and minimize the growth of algae and bacteria.

The hydraulic conductivity of the peat treatment system decreased during the first 3 months of operation resulting in higher water levels for the same flow rate. Establishment of an algae layer on top of the substrate in each tank also roughly coincided with the development of diurnal swings in the tank water levels and the slow overall rising of the water levels. The hydraulic conductivity for Tank 1 started at $0.084 \mathrm{~cm} / \mathrm{sec}$ in late June and decreased by an order of magnitude to $0.0061 \mathrm{~cm} / \mathrm{sec}$ by early September. However, the rate of change in hydraulic conductivity has been slowing down and may eventually cease depending on the cause for the reduction. Continued operation of the pilot study will provide information on any further reduction in hydraulic conductivity and its effect on operation. The decline in hydraulic conductivity might have been due to:

- Swelling of the peat due to hydration

- Retention and subsequent growth of biomass (algae) introduced into the peat-bed tank from the Outfall H12 water

- The development of a biofilm and growth of microorganisms in the peat.

Based on the results of the peat-bed pilot study, SRNL recommends the following:

- Continue to consider the peat bed approach as the back-up technology option for Outfall H-12 in the event that the source reduction, recalculation of limits, and dissolved organic carbon addition options fail to obtain SCDHEC approval. Use of the Premier Pro-Moss TBK or similar form of peat would be preferable to the APTsorb peat due to its superior performance and lower cost. Provision for temporary adjustment of $\mathrm{pH}$ at the effluent is recommended. Providing a light-blocking cover for the peat beds to prevent the growth of algae and subsequent development of a pore-clogging biofilm is strongly recommended. Design would need to incorporate sufficient freeboard in the peat beds to account for potential daily fluctuation in water levels and decrease in hydraulic conductivity over time.

- Consider the use of the peat bed technology as a treatment method elsewhere on site for smaller flows where the peat bed can be covered to minimize algal/bacterial/biofilm growth and in locations where piping would not have to be extensively rerouted (a large factor in raising the costs for peat bed implementation at Outfall H-12).

- Continue operating the pilot study through cold weather months to:

- Determine the effect of the cold weather on the algae growth and determine whether that changes the hydraulic conductivity

- Continue to track the decreasing hydraulic conductivity over time to determine if it will reach a stable point, as it appears it might be doing

- See if the diurnal change in the water levels is related to the temperature

- Potentially test additional cost-effective methods of algae control since the ultrasonic device has not been effective. 


\section{References}

American Peat Technology. 2007. APTsorb: More Information and Specifications. http://americanpeattech.com/ aptsorb3.htm. American Peat Technology, Aitken, MN.

Baird, A.J. and S.W. Gaffney. 2000. Solute movement in drained fen peat: a field trace study in a Somerset (UK) wetland. Hydrological Processes 14: 2489-2503.

Berry, C.J. 2007. Bench Scale Peat Studies for H-12 Outfall, SRNL-ESB-2007-00031 (Draft). Savannah River National Laboratory, Washington Savannah River Company, Aiken, SC.

Canadianpond.ca Products Limited. 2007. Ultra Sonic Algae Control. http://www.canadianpond.ca/lgsonic.htm. Accessed 9/24/07. Canadianpond.ca Products Limited . Knowlton, Quebec, Canada.

Halverson, N.V. and R.L. Nichols. 2007. Task Technical and Quality Assurance Plan: Pilot Peat-Bed Treatment System for NPDES Outfall H-12, SRNL-ESD-2007-00059 Rev. 1. Savannah River National Laboratory, Washington Savannah River Company, Aiken, SC.

Hoag, R.S. and J.S. Price. 1997. The effects of matrix diffusion on solute transport and retardation in undisturbed peat in laboratory columns. Journal of Contaminant Hydrology 28: 193-205.

LG Sound. 2007. Frequently Asked Questions and the Answers. http://www.lgsonic.com/LG\%20SONIC\%20EN/ faq.htm. 10/4/07. LG Sound, Netherlands.

Mullinax, B. 2007. Study Plan - Peat Bed Pilot Study at SRS Outfall H-12 Dated May 1, 2007. Memorandum to B. Payne dated May 17, 2007. South Carolina Department of Health and Environmental Control. Columbia, SC.

Nelson, E.A. 2007a. Calculated pH Shift in Pilot Study. e-mail to E. McNamee, A. Morrow and M. Patel dated 8/15/07. Savannah River National Laboratory, Washington Savannah River Company, Aiken, SC.

Nelson, E.A. 2007b. Predicted Radionuclide and Metal Accumulation in Peat Beds (807-1H and 807-2H), S-CLCH-01123. Savannah River National Laboratory, Washington Savannah River Company, Aiken, SC.

Nelson, E.A. 2007c. Retention Time Effect on Metal Removal by Peat Columns, WSRC-STI-2007-00089. Savannah River National Laboratory, Washington Savannah River Company, Aiken, SC.

Nelson, E.A. and W.L. Specht. 2005. Bench Scale Demonstration of a Peat Bed for Removal of Metals at the H-12 Outfall, WSRC-TR-2005-00566. Savannah River National Laboratory, Westinghouse Savannah River Company, Aiken, SC.

Paulson, E. 2007. Re: APTsorb Media. e-mail to M. Patel dated 6/6/2007. American Peat Technology, LLC, Aitkin, MN.

Premier Horticulture. 2007. Technical Data: Pro-Moss TBK. http://www.premierhort.com/eProMix/pdf/TD1-PROMOSSTBK-OLDS.pdf. Accessed 6/20/07. Premier Horticulture, Dorval, Quebec, Canada.

Rizzuti, A.M., A.D. Cohen, and E.M. Stack. 2004. Using hydraulic conductivity and micropetrography to assess water flow through peat-containing wetlands. International Journal of Coal Geology 60: 1-16.

Shibchurn, A., P.J. Van Geel and P.L. Kennedy. 2005. Impact of density on the hydraulic properties of peat and the time domain reflectometry (TDR) moisture calibration curve. Can. Geotech. J. 42: 279-286.

Shipman, J.M. and W.C. Bugher. 2004. NPDES Permit Compliance Alternatives Study Report, Y-ESR-G-00001. Westinghouse Savannah River Company, Aiken, SC. 
Westinghouse Savannah River Company. 2007. H-12 NPDES Outfall Corrective Action Alternatives Study, WSRCRP-2007-04016. Westinghouse Savannah River Company, Aiken, SC.

Yeager, C. 2007. Peat Bed Algae. Interoffice Memorandum to N. V. Halverson dated 10/3/07. Savannah River National Laboratory, Washington Savannah River Company, Aiken, SC. 


\section{APPENDIX 1: Pro-Moss TBK Specifications}

Premier Horticulture’s Pro-Moss TBK Technical Data Sheet

Premier

Horticulture

\section{technical data PROMNOSS.}

\section{FIBROUS BLOND SPHAGNUM PEAT MOSS}

PRO-MOSS 'TBK' is made of a select long-fibered blond Sphagnum peat moss for general commercial use. PROMOSS 'TBK' provides a high degree of water retention and air porosity for a wide range of applications. Ideal for use as a major component in horticultural growing media and mushroom casing materials which require high fibrosity.

PRODUCTION FACILITY:

Caribou (Manitoba), Canada

PACKAGE SPECIFICATIONS:

\begin{tabular}{|c|c|c|c|c|} 
Code & $\begin{array}{c}\text { Size } \\
\text { (cu.ft.) }\end{array}$ & Packing & $\begin{array}{c}\text { Weight } \\
\text { (b) }\end{array}$ & $\begin{array}{c}\text { Minimum Yield } \\
\text { (cu.ft.) }\end{array}$ \\
\hline $0010 \mathrm{P}$ & 55 & $2 /$ pallet & $800-1050$ & 113.0 \\
\hline $0023 \mathrm{P}$ & 6.0 & 18 /pallet & $85-95$ & 12.6 \\
\hline $0060 \mathrm{P}$ & 3.8 & $30 /$ pallet & $55-70$ & 7.6 \\
\hline
\end{tabular}

\section{LABORATORY ANALYSIS*}

CHEMICAL CHARACTERISTICS:

$\mathrm{pH}:$

Electrical Conductivity:

C/N Ratio:

Cation Exchange Capacity:

Organic Matter:

Ash Content:

PHYSICAL CHARACTERISTICS:

Total Porosity:

Dry Bulk Density:

Fresh Bulk Density:

Water-Holding Capacity:

Moisture Content:
$3.9-4.9(1: 3$, v:v water)

$0.09-0.25 \mathrm{mmhos} / \mathrm{cm}$

$125-135$

$150-250 \mathrm{meq} / 100 \mathrm{~g}$

$92-96 \%$

$4-8 \%$

DRY GRANULOMETRY:

\begin{tabular}{rr} 
Mesh Size & $\%$ Passing \\
\hline 10 mesh: & $70-85 \%$ \\
20 mesh: & $50-65 \%$ \\
50 mesh: & $20-35 \%$ \\
100 mesh: & $8-18 \%$
\end{tabular}

\footnotetext{
* This data is for information purposes only. Peat mose is a natural product; therefore, resuits for individual samples may vary to a limited degree.
}

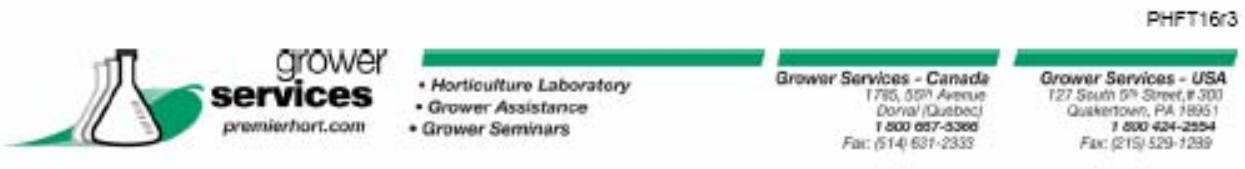

Source: Premier Horticulture (2007) 


\section{APPENDIX 2: APTsorb Specifications}

American Peat Technology’s APTsorb Specifications

\begin{tabular}{|c|c|}
\hline Parameter & Value \\
\hline Moisture & $<2 \%$ \\
\hline Size & 10 to 30 mesh \\
\hline $\mathrm{pH}$ & 6.2 to 7.2 \\
\hline Metals capacity & $2 \%$ to $7 \%$ by weight \\
\hline Density & $41 \mathrm{lb} / \mathrm{cu} \mathrm{ft}$ \\
\hline Working pH range & 4.0 to 7.5 \\
\hline
\end{tabular}

Source: American Peat Technology (2007) 


\section{APPENDIX 3: Time Line}

TIME LINE

\begin{tabular}{|c|c|}
\hline Date & Event \\
\hline $5 / 31 / 07$ & $\begin{array}{l}\text { 11:45 - Started filling Tank } 1 \text { from the bottom at } 0.9 \mathrm{gpm} \text {. } \\
\text { 12:00 - Rate lowered to } 0.6 \mathrm{gpm} \text {. } \\
\text { 16:00 - Increased for over night to } 1.0 \mathrm{gpm} .\end{array}$ \\
\hline $6 / 1 / 07$ & $\begin{array}{l}\text { 08:45 - Water level about a foot above the peat. Replaced upper leaking } \\
\text { valve. } \\
\text { 08:50 - Turned off pump. Let sit over the weekend to hydrate. }\end{array}$ \\
\hline $6 / 4 / 07$ & $\begin{array}{l}\text { 09:25 - Reconnected power. Lowered the discharge arm to start flow. } \\
\text { Started pump. Flow in stream was murky, } \\
\text { 14:43 - Water level had dropped from } 1850 \text { gallon mark on tank to } 1700 \\
\text { gallon mark. Collected first set of samples. }\end{array}$ \\
\hline $6 / 5 / 07$ & $\begin{array}{l}\text { 09:30 - Pump not running. Breaker had tripped at the power pole. Water } \\
\text { level was } 3 \mathrm{~cm} \text { above the } 1600 \text { gallon line. Restarted the pump. } \\
\text { 13:30 - Taped electrical line connections to prevent moisture from } \\
\text { tripping GFI. }\end{array}$ \\
\hline $6 / 11 / 07$ & $\begin{array}{l}\text { 09:25 - Pump off due to tripped GFI. Reset GFI and pump restarted. } \\
\text { Changed out HOBO data logger for a different one. Confirmed } \\
\text { flow meter working. Multimeter reading } 5.30 \mathrm{~mA} \text { and flow } \\
\text { reading of 0.82. }\end{array}$ \\
\hline $6 / 12 / 07$ & $\begin{array}{l}\text { 09:00 - Pump off due to tripped GFI. Tried to restart, but it tripped again. } \\
\text { No sampling because the water had been sitting too long. } \\
\text { 14:30 - Changed power cord to a longer one to eliminate the exposed } \\
\text { joint. Restarted. }\end{array}$ \\
\hline $6 / 13 / 07$ & $\begin{array}{l}\text { 14:20 - Pump off due to tripped GFI. Reset it and it started. No sampling } \\
\text { because the water had been sitting too long. }\end{array}$ \\
\hline $6 / 14 / 07$ & $\begin{array}{l}\text { Early - Pump off due to tripped GFI. Tried to restart, but it tripped again. } \\
\text { 10:45 - Replaced breaker. }\end{array}$ \\
\hline $6 / 18 / 07$ & $\begin{array}{l}\text { 14:15 - No water being discharged to } \mathrm{H}-12 \text {. Water level in the small } \\
\text { pool at pump intake is dropping. Called various people to } \\
\text { determine problem. } \\
\text { 14:33 - Turned off pump. }\end{array}$ \\
\hline $6 / 19 / 07$ & 09:30 - Started pump. \\
\hline $6 / 20 / 07$ & $\begin{array}{l}\text { 09:00 - Pump stopped working shortly personnel arrived at the site. } \\
\text { Collected inlet samples from the water at the top of the tank } \\
\text { since no new water was flowing in. Replaced pump with a new } \\
\text { one and restarted. }\end{array}$ \\
\hline $6 / 25 / 07$ & 09:00 - Tank 2 internally complete. \\
\hline $6 / 26 / 07$ & 09:30 - Assembled plumbing for Tank 2. \\
\hline $6 / 27 / 07$ & $\begin{array}{l}\text { 09:15 - Installed flow meter for Tank } 2 . \\
\text { 10:42 - Started filling Tank 2. Tank } 2 \text { flow } 0.6 \text { gpm, filling from the } \\
\text { bottom. }\end{array}$ \\
\hline 6/28/07 & $\begin{array}{l}\text { Temporarily stopped filling Tank } 2 \text { and let it sit over the weekend and } \\
\text { the holiday to hydrate. }\end{array}$ \\
\hline
\end{tabular}


TIME LINE (cont.)

\begin{tabular}{|c|c|}
\hline Date & Event \\
\hline $7 / 3 / 07$ & $\begin{array}{l}\text { 10:25 - Water flowing to Tank } 1 \text { but flow meter reading } 0 \text {. Propeller not } \\
\text { working. Removed the meter, freed the propeller, reconnected, } \\
\text { and restarted the pump. Flow was } 1.5 \text { at } 188 \mathrm{hz} \text {. Reduced flow } \\
\text { to } 1.0 \text { at } 134 \mathrm{hz} \text {. Algae were growing in the flow meter. Made } \\
\text { a cover out of tape for the meter to block light. }\end{array}$ \\
\hline $7 / 5 / 07$ & $\begin{array}{l}\text { 10:35 - Began filling Tank } 2 \text { again at } 0.5 \text { gpm. } \\
\text { Note: noticeable algae were accumulating on surface of pea gravel and } \\
\text { walls in Tank } 1 .\end{array}$ \\
\hline $7 / 6 / 07$ & $\begin{array}{c}\text { 11:30 - Stopped filling Tank 2. Water level was } 1375 \text { gallons as marked } \\
\text { on the tank. Let peat hydrate in Tank } 2 \text { over the weekend. }\end{array}$ \\
\hline 7/9/07 & $\begin{array}{l}\text { 09:30 - Connected Tank } 2 \text { to the system. } \\
\text { 09:40 - Began operating both tanks. Flow rate in each tank was about } 1 \\
\text { gpm and pump speed was } 260 \mathrm{hz} \text {. } \\
\text { 15:45 - Breaker was tripped and system was off. Restarted and set pump } \\
\text { speed to } 220 \mathrm{hz} \text {. Flow was } 1 \text { gpm to each tank. }\end{array}$ \\
\hline $7 / 11 / 07$ & $\begin{array}{l}\text { Decision made to cut the retention time to } 2 \text { hours instead of } 4 \text { hours in } \\
\text { the peat bed design to cut the bed size in half. Design flow will have to } \\
\text { be doubled. }\end{array}$ \\
\hline 7/12/07 & $\begin{array}{l}\text { 10:00 - Power off. Reset the breaker and restarted, but the breaker } \\
\text { tripped again. No samples. }\end{array}$ \\
\hline $7 / 13 / 07$ & $\begin{array}{l}\text { Replaced pump. Increased flow to } 2 \text { gpm for each tank in response to } \\
7 / 11 / 07 \text { decision to cut peat bed size in half. }\end{array}$ \\
\hline $7 / 20 / 07$ & $\begin{array}{l}\text { AM - Used brush to clean scum off the intake pipe and screen in the } \\
\text { stream. Algae were definitely growing on the tank sides and the } \\
\text { surface of the gravel in Tank } 1 \text {. }\end{array}$ \\
\hline $7 / 26 / 07$ & $\begin{array}{l}\text { 13:15 - Flow meter was off, but pump was running and water flowing. } \\
\text { Reset portable circuit guard and the flow meter started up again. } \\
\text { NOTE: Stopped daily sampling of Tank } 2 \text { before the end of the planned } \\
\text { four week period and switched to weekly due to low copper in the } \\
\text { influent. Sampling frequency will be increased for a while when the } \\
\text { copper addition equipment is installed. }\end{array}$ \\
\hline $7 / 30 / 07$ & $\begin{array}{l}\text { 10:52 - Design Authority sent e-mail about increase in tank water depth. } \\
\text { 03:30 - SRNL confirmed apparent increase and marked water depth. } \\
\text { Mark is 28.25” above the deck for Tank } 1 \text { and 18.5” above the } \\
\text { deck for Tank 2. }\end{array}$ \\
\hline $7 / 31 / 07$ & $\begin{array}{l}\text { 09:30 - Tank } 1 \text { level about 2" - 3" higher than the mark made yesterday. } \\
\text { Installed In-Situ pressure transducers in each tank to monitor } \\
\text { water depth. Measured 8.5” head for tank } 1 \text { when the flow read } \\
\text { 2.18 gpm. Lowered discharge line } 3 \text { links, The discharge } \\
\text { elevation now } 19.25 \text { " above the deck. }\end{array}$ \\
\hline $8 / 1 / 07$ & 09:45 -Tank 1 water level was at the 7/30/07 mark. \\
\hline $8 / 20 / 07$ & $\begin{array}{l}\text { 09:45 - Installed ultrasonic algae controller. } \\
\text { 11:13 - Installed and started copper addition system. }\end{array}$ \\
\hline $8 / 27 / 07$ & $\begin{array}{l}\text { Approx. 10:20 - Initiated screening WER on } 8 \mathrm{H} \text { basin discharge by } \\
\text { rerouting cooling water flow through } 8 \mathrm{H} \text { basin. No apparent } \\
\text { effect on flows to the pilot study. }\end{array}$ \\
\hline $\begin{array}{l}\text { Approx. } \\
\text { 9/9/07 }\end{array}$ & $\begin{array}{l}\text { Copper addition system ran out of the copper (II) chloride over the } \\
\text { weekend. }\end{array}$ \\
\hline
\end{tabular}




\section{TIME LINE (cont.)}

\begin{tabular}{|l|l|}
\hline Date & Event \\
\hline $9 / 10 / 07$ & $\begin{array}{c}11: 16 \text { - Samples pulled do not have added copper because the tank } \\
\text { emptied over the weekend. Copper (II) chloride tank was } \\
\text { refilled. }\end{array}$ \\
\hline $9 / 11 / 07$ & $\begin{array}{c}\text { Pump for copper addition system not moving the copper solution. Pump } \\
\text { re-primed. System back operating. }\end{array}$ \\
\hline $9 / 14 / 07$ & $\begin{array}{c}09: 17 \text { - Lowered the discharge line for Tank 1 by two links on the chain. } \\
\text { Water level was 4" above the line marked on the tank. Water } \\
\text { level in Tank 2 was about 2" above the mark on that tank. }\end{array}$ \\
\hline $9 / 18 / 07$ & $\begin{array}{c}10: 00 \text { - Noted that there was less floating algae in Tank 1 than Tank 2. } \\
\text { Hard to discern any other effect from the ultrasonic algae } \\
\text { controller in Tank 1. }\end{array}$ \\
\hline
\end{tabular}




\section{APPENDIX 4: Duplicate Sample Results}

Duplicate Sample Results for Metals

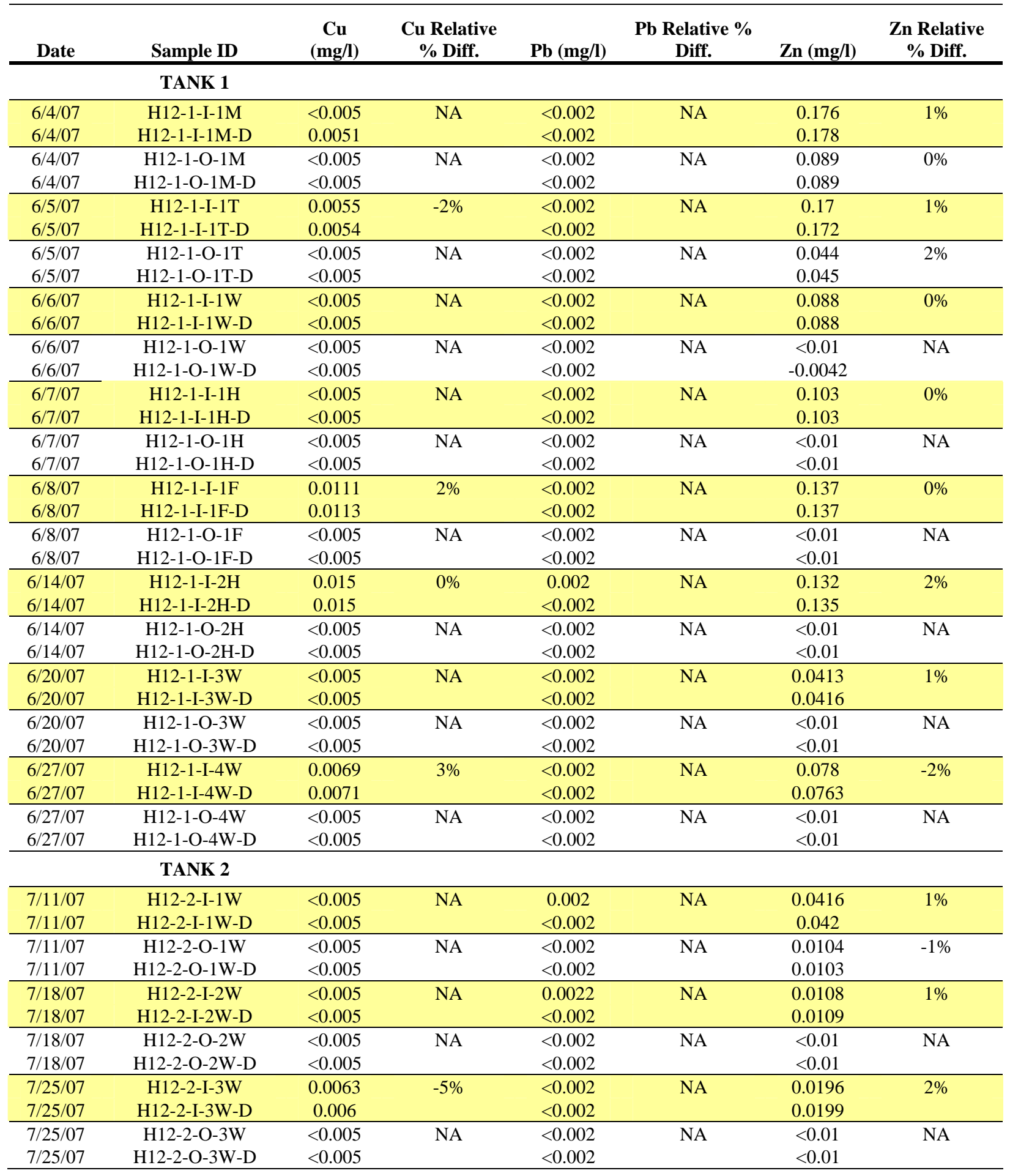

